\title{
Distribution of iron- and sulfate-reducing bacteria across a coastal acid sulfate soil (CASS) environment: implications for passive bioremediation by tidal inundation
}

OPEN ACCESS

Edited by:

Stuart Findlay,

Cary Institute of

Ecosystem Studies, USA

Reviewed by:

Wei Shi,

North Carolina State University, USA

Mike Grace,

Monash University, Australia

*Correspondence:

Yu-Chen Ling and John W. Moreau, School of Earth Sciences, University of Melbourne, Parkville,

VIC 3010, Australia

Ichaco/@gmail.com; jmoreau@unimelb.edu.au

Specialty section:

This article was submitted to Terrestrial Microbiology,

a section of the journal

Frontiers in Microbiology

Received: 21 November 2014 Accepted: 08 June 2015 Published: 03 July 2015

Citation:

Ling Y-C, Bush R, Grice K, Tulipani S, Berwick L and Moreau JW (2015)

Distribution of iron- and sulfate-reducing bacteria across a coastal acid sulfate soil (CASS) environment: implications for passive bioremediation by tidal inundation.

Front. Microbiol. 6:624.

doi: 10.3389/fmicb.2015.00624

\author{
Yu-Chen Ling ${ }^{1 *}$, Richard Bush ${ }^{2}$, Kliti Grice ${ }^{3}$, Svenja Tulipani ${ }^{3}$, Lyndon Berwick ${ }^{3}$ and \\ John W. Moreau ${ }^{1 *}$
}

\begin{abstract}
${ }^{1}$ School of Earth Sciences, University of Melbourne, Melbourne, VIC, Australia, ${ }^{2}$ Southern Cross GeoScience, Southern Cross University, Lismore, NSW, Australia , ${ }^{3}$ Department of Chemistry, Western Australia Organic and Isotope Geochemistry Centre, The Institute for Geoscience Research, Curtin University, Perth, WA, Australia
\end{abstract}

Coastal acid sulfate soils (CASS) constitute a serious and global environmental problem. Oxidation of iron sulfide minerals exposed to air generates sulfuric acid with consequently negative impacts on coastal and estuarine ecosystems. Tidal inundation represents one current treatment strategy for CASS, with the aim of neutralizing acidity by triggering microbial iron- and sulfate-reduction and inducing the precipitation of iron-sulfides. Although well-known functional guilds of bacteria drive these processes, their distributions within CASS environments, as well as their relationships to tidal cycling and the availability of nutrients and electron acceptors, are poorly understood. These factors will determine the long-term efficacy of "passive" CASS remediation strategies. Here we studied microbial community structure and functional guild distribution in sediment cores obtained from 10 depths ranging from 0 to $20 \mathrm{~cm}$ in three sites located in the supra-, inter- and sub-tidal segments, respectively, of a CASS-affected salt marsh (East Trinity, Cairns, Australia). Whole community 16S rRNA gene diversity within each site was assessed by 454 pyrotag sequencing and bioinformatic analyses in the context of local hydrological, geochemical, and lithological factors. The results illustrate spatial overlap, or close association, of iron-, and sulfate-reducing bacteria (SRB) in an environment rich in organic matter and controlled by parameters such as acidity, redox potential, degree of water saturation, and mineralization. The observed spatial distribution implies the need for empirical understanding of the timing, relative to tidal cycling, of various terminal electron-accepting processes that control acid generation and biogeochemical iron and sulfur cycling.

Keywords: acid sulfate, microbial community, iron-reducing, sulfate-reducing, iron sulfides, geomicrobiology, wetlands, remediation 


\section{Introduction}

Coastal acid sulfate soils (CASS) constitute a major global environmental problem (Dent and Pons, 1995; White et al., 2007; Ljung et al., 2009). The resulting problems include fish kills (Powell and Martens, 2005; Stephens and Ingram, 2006), decreased rice yields (Bronswijk et al., 1995), release of greenhouse gases such as methane and dinitrogen oxide (Denmead et al., 2007), sulfur dioxide emissions (Macdonald et al., 2004), construction damage (Crammond, 2002), and changed mobility of toxic metals (Burton et al., 2008). In Australia, roughly $\$ 10$ billion worth of acid sulfate soil "legacy" impacts remain (Fitzpatrick, 2003), and Australia contains only about $18 \%$ of acid sulfate soils worldwide (Ljung et al., 2009).

Although some CASS environments result from tectonic uplift (Åström and Björklund, 1995), anthropogenic drainage of wetlands generally accounts for most recent and modern CASS formation (Rosicky et al., 2004; Ljung et al., 2009). Drainage allows oxygen to penetrate further into the subsurface, resulting in oxidation of iron sulfides and release of protons and sulfuric acid. For instance, the oxidation of pyrite by molecular oxygen (Hicks et al., 1999):

$$
\mathrm{FeS}_{2}+3.75 \mathrm{O}_{2}+3.5 \mathrm{H}_{2} \mathrm{O} \rightarrow \mathrm{Fe}(\mathrm{OH})_{3}+4 \mathrm{H}^{+}+2 \mathrm{SO}_{4}^{2-}
$$

releases 4 moles of acid and 2 moles of sulfate per mole of pyrite. Microbial intervention will expedite the reaction rate by co-oxidation of ferrous iron, with the product $\mathrm{Fe}^{3+}$ acting as a strong oxidant of pyrite.

Low $\mathrm{pH}$ pore waters promote the mobility of toxic heavy metals such as aluminum and manganese (Willett et al., 1992; Sammut et al., 1996), which can be partitioned into metal-sulfides (Moreau et al., 2013). A pH decrease from 3.7 to 1.9 can result in a dissolved aluminum increase from 0.9 to $40 \mathrm{M}$ (Van Breemen, 1973). Aluminum hydrolysis generates 3 moles of acid from one mole of aluminum and decreases $\mathrm{pH}$ further (Hicks et al., 1999):

$$
\begin{aligned}
\mathrm{Al}^{3+}+\mathrm{H}_{2} \mathrm{O} & \rightarrow \mathrm{Al}(\mathrm{OH})^{2+}+\mathrm{H}^{+} \\
\mathrm{Al}(\mathrm{OH})^{2+}+\mathrm{H}_{2} \mathrm{O} & \rightarrow \mathrm{Al}(\mathrm{OH})_{2}^{+}+\mathrm{H}^{+} \\
\mathrm{Al}(\mathrm{OH})_{2}^{+}+\mathrm{H}_{2} \mathrm{O} & \rightarrow \mathrm{Al}(\mathrm{OH})_{3}+\mathrm{H}^{+}
\end{aligned}
$$

The most common treatments for CASS-related contamination are lime neutralization and seawater inundation (White et al., 1997; Johnston et al., 2009a,b). The primary disadvantage of lime treatment is the relatively high cost and need for extensive and continued maintenance. In the Great Barrier Reef catchments in Australia, it was estimated that $\$ 62$ million AUD would be needed for lime treatment over $6.7 \times 10^{5}$ hectares of CASSaffected regions (Powell and Martens, 2005). However, lime addition accounts for less than $1 \%$ of the alkalinity in a limeassisted tidal inundation treatment (Johnston et al., 2012). Reflooding by seawater is hence a more cost effective treatment strategy, as marine bicarbonate accounts for $25 \sim 40 \%$ of total alkalinity generation (Johnston et al., 2012). The processes of microbial sulfate and iron reduction triggered by seawater flooding contribute to more than $50 \%$ of total alkalinity
(Johnston et al., 2012). Both iron and sulfate reduction consume protons:

$$
\begin{aligned}
\mathrm{Fe}(\mathrm{OH})_{3}+0.25 \mathrm{CH}_{2} \mathrm{O}+2 \mathrm{H}^{+} & \rightarrow \mathrm{Fe}^{2+}+0.25 \mathrm{CO}_{2}+2.75 \mathrm{H}_{2} \mathrm{O}(5) \\
\mathrm{SO}_{4}^{2-}+2\left(\mathrm{CH}_{2} \mathrm{O}\right) & \rightarrow 2 \mathrm{HCO}_{3}^{-}+\mathrm{H}_{2} \mathrm{~S}
\end{aligned}
$$

and can lead to formation of mackinawite $(\mathrm{FeS})$ or pyrite $\left(\mathrm{FeS}_{2}\right)$, both of which can promote the immobilization of arsenic, a common toxic metalloid in CASS environments (Burton et al., 2011).

Microorganisms can also influence other biogeochemical cycles in natural and contaminated wetlands. However, little research has been conducted to provide detailed information about microbial processes and bioremediation efficiency specifically in CASS systems. Previous microbiological studies of CASS-like systems have discussed the vertical depth-distribution of sulfur- and iron-oxidizing bacteria in a paddy field (Ohba and Owa, 2005), revealed high microbial biomass and activity at the Baltic coast, Finland (Simek et al., 2013) and compared microbial communities from Ostrobothnian, Finland, with those found in acid mine drainage (AMD) (Wu et al., 2013). To understand the potential for microbial acid generation and biogeochemical cycling in CASS-impacted sediments, a comprehensive, spatially integrative resolution of microbial "functional guild" distribution is required. Specifically, we need to know more about the distribution and diversity of sulfurand iron-cycling microorganisms. Previous studies have long established that iron reducing bacteria (IRB) can out-compete sulfate reducing bacteria (SRB) for limited electron donor when the environment is non-limiting in ferric iron (e.g., Lovley and Phillips, 1987; Chapelle and Lovley, 1992). However, we hypothesized that increases in the concentrations of organics in CASS systems decrease competition between IRB and SRB by increasing thermodynamic energy availability relative to enzyme kinetics. We present results and analyses from an investigation of whole community $16 \mathrm{~S}$ rRNA genes amplified from CASS-impacted sediments from the East Trinity wetlands (Cairns, Australia), a tidally influenced wetland located on the northeast coast of Australia. Gene data are interpreted in the context of environmental and organic geochemical data acquired from the site. The results of this study were analyzed in the context of soil type and sediment lithology, degree of pore water saturation, tidal inundation and turbidity, acidity and organic carbon availability to understand the factors that shape microbial community structure and activity.

\section{Materials and Methods}

\section{Field Site and Soil Sampling}

The majority of CASS environments were formed during the last Holocene post-glacial period, as rising sea levels promoted the deposition of iron sulfide minerals (Dent, 1986). The East Trinity wetlands study site is characterized by abundant potential CASS in Holocene soil layers that formed when high rates of organic matter degradation under warm temperatures stimulated iron and sulfate reduction (White et al., 1997). In the 1970s, 
large-scale drainage of seawater exposed CASS to air and resulting in soil acidification and heavy metal contamination problems in this area and nearby ecosystems. Since 2001, tidal exchange remediation is being practiced in this area (QASSIT, 2000).

The $\mathrm{pH}$ and Eh values of each core section were measured in the field with a portable $\mathrm{pH} / \mathrm{Eh}$ meter by Thermo Scientific Orion 5-Star Portable Plus pH/ORP/ISE/Conductivity/DO meter with a Model 9678BN Pt-Ag/AgCl combination electrode. ORP measurements were calibrated to a standard hydrogen electrode at $20^{\circ} \mathrm{C}$. The resolution and relative accuracy of $\mathrm{pH}$ and ORP are 0.01 and \pm 0.002 , and $0.1 \mathrm{mV}$ and \pm 0.2 , or $0.05 \%$, respectively. Soil samples were collected from a sub-catchment of Firewood Creek in the East Trinity Wetland $\left(145^{\circ} 80^{\prime} \mathrm{E}\right.$, $16^{\circ}$ 94'S), northeast Australia (Burton et al., 2011; Johnston et al., 2012). Three $20 \mathrm{~cm}$-deep sediment cores were collected along an upland to seawater transect (Figure 1, sampling sites A1 to A3, respectively) during a low tide period, and then sectioned into $2 \mathrm{~cm}$ intervals. Sediments were collected into $15 \mathrm{~mL}$ sterile bottles containing $3 \mathrm{~mL}$ of RNAlater ${ }^{\mathrm{TM}}$ RNA stabilization reagent and then preserved at $-80^{\circ} \mathrm{C}$ in a freezer until DNA extractions were performed. Chemical data were measured in the field by insertion of the electrode into soil/pore water at each of the sampling depths, with several rinses with nanopure water in between measurements. The sampling transects incorporated both the surface, or $\mathrm{O}$ horizon consisting of surficial organic deposits (Johnston et al., 2011b, 2012), and sulfuric horizon, consisting of actual acid sulfate soils characterized by low soil $\mathrm{pH}$ (Hicks et al., 1999).

\section{Organic Geochemistry Analyses}

Organic geochemical analyses were performed on aliquots of the top $6 \mathrm{~cm}$ of sediment cores from the transect $(\mathrm{A} 1-\mathrm{A} 3)$ and two control sites located (i) outside of the tidal bund-wall (not affected by drainage and CASS formation; "Mangrove Site") and (ii) at an CASS site not treated with tidal inundation ("Acidic Site"). The samples were freeze-dried, homogenized and Soxhlet-extracted $(48 \mathrm{~h})$ in a mixture of dichloromethane (90\%) and methanol (10\%). Elemental sulfur was removed with activated copper pellets. The extracts were separated into three fractions (aliphatics, aromatic and polar) by silica gel column chromatography using eluents of increasing polarity (e.g., Nabbefeld et al., 2010). Aliquots of the dried polar fractions were derivatised in a 3:2 mixture of bis(trimethylsilyl)trifluoroacetamide (BSTFA) and anhydrous pyridine for (20 min) at $60-70^{\circ} \mathrm{C}$ and analyzed using GC-MS within a few hours.

Gas chromatography-mass spectrometry (GC-MS) analyses of aromatic and derivatised polar fractions were performed on an Agilent 6890/5973 GC-MS equipped with an Agilent 6890 autosampler and a $60 \mathrm{~m} \times 0.25 \mathrm{~mm}$ i.d. $\times 0.25 \mu \mathrm{m}$ film thickness DB5-MS column (J\&W Scientific). Aromatic fractions were injected in splitless mode. Polar fractions were injected in splitless cool on column mode into an Alltech pre-column $(2 \mathrm{~m} \mathrm{x} 0.53 \mathrm{~mm}$ i.d.) fitted to the DB5-MS column. Helium was used as a carrier gas at a constant flow of 1.1 and $1.2 \mathrm{~mL} / \mathrm{min}$ for aromatic and polar fractions, respectively. The GC oven was heated from 40 to $325^{\circ} \mathrm{C}$ at $3^{\circ} \mathrm{C} / \mathrm{min}$ with initial and final hold times of 1 and $30 \mathrm{~min}$ for aromatic fractions and from 50 to $320^{\circ} \mathrm{C}$ at $6^{\circ} \mathrm{C} / \mathrm{min}$ with initial and final hold times of 1 and $20 \mathrm{~min}$ for polar fractions. The MS was operated at $70 \mathrm{eV}$ and acquired full scan mass spectra (50-550 Daltons and 50-750 Daltons for aromatic and polar fractions, respectively) at $\sim 3$ scans/s and a source temperature of $230^{\circ} \mathrm{C}$. Peak assignments were based on correlation of GC retention time and mass spectral data with reference compounds, library spectra or other published data.

\section{DNA Extraction and 454 Pyrosequencing}

Each DNA extraction used $\sim 0.3 \mathrm{~g}$ of sediments (wet weight) with the PowerSoil DNA Isolation Kit (Mo Bio Laboratories, Inc. Carlsbad, CA) according to the manufacturer's protocol.

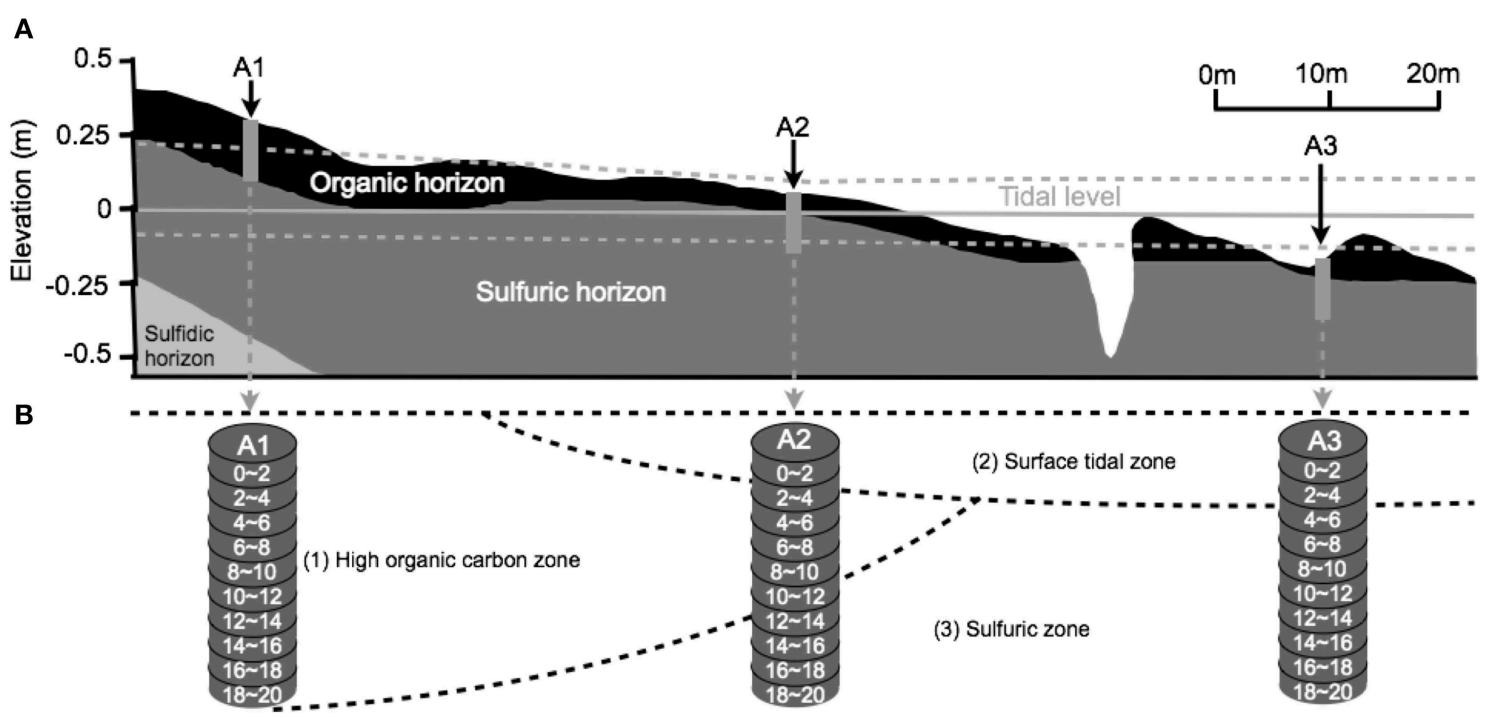

FIGURE 1 | The distribution of soil layers, water saturation state, and $\boldsymbol{\beta}$ diversity. (A) The in situ soil layers, water saturation state, and sampling sites. (B) Three zones at East Trinity site divided by $\beta$ diversity. Figures are modified from Burton et al. (2011) and Johnston et al. (2011a,b). 
DNA samples were sent for 454 pyrosequencing at the Australian Centre for Ecogenomics (ACE; Brisbane, Australia). A first round of PCR was conducted with SSU803F (combinations of $803 \mathrm{Fa} 5^{\prime}$ TTAAGATACCCTGGTAGTC-3' ${ }^{\prime}, 803 \mathrm{Fb} 5^{\prime}$-TTAGATACCCSG GTAGTC-3', 803Fc 5'-TTAGATACCCTHGTAGTC-3', 803Fd $5^{\prime}$-TTAGATACCCTGGTAGTC-3' ${ }^{\prime}$ in a ratio of $2: 1: 1: 1$, E. coli position 2305-2322, Brosius et al., 1981) and SSU1392R ( $5^{\prime}$ ACG GGC GGT GWG TRC-3', E. coli position 2908-2923, Brosius et al., 1981) primers used in the Fisher kit, with $1 \mathrm{U}$ Taq, dNTP at a final concentration of $0.2 \mathrm{mM}$, primers at a final concentration of $0.2 \mu \mathrm{M}, \mathrm{MgCl}_{2}$ at a final concentration of $2 \mathrm{mM}$ and BSA at a final concentration of $0.3 \mathrm{mg} / \mathrm{mL}$. Thermal cycling had an annealing temperature of $55^{\circ} \mathrm{C}$ with 30 cycles. ACE has done extensive testing with this protocol and biases in amplication have been minimized. Then $2 \mu \mathrm{L}$ of the first PCR product was used for a second PCR with no clean up to add barcodes (Multiplex Identifiers, MIDs), using the same reagents and conditions as for the first PCR but for 10 cycles. The PCR products were then quantified on the TapeStation and pooled at equal concentrations. The pooled DNA was gel extracted and amplified by emulsion PCR for sequencing. The Roche 454 sequencing (GS FLX Titanium chemistry) was performed with Roche 454 protocols.

\section{6s rRNA Gene Sequences Analyses}

DNA sequences were analyzed using the software environment Mothur (Schloss et al., 2009) v.1.32.1 following the Mothur 454 SOP (accessing date: Dec 2013) (Schloss et al., 2011). Raw sequence data were deposited to the Sequence Read Archive (SRA) of NCBI under the accession number: PRJNA275357. Sequences were removed for which the average quality dropped below 35 . This step removed 7605 of a total 169,237 reads. Unique sequences were identified and the closest reference sequences were selected from SILVA bacterial and archaeal databases by the kmer search method, followed by a needleman alignment to make pairwise alignments between reference and candidate sequences (Schloss, 2010). Aligned sequences were checked to keep the most overlapping positions. Alignment results showed that $97.5 \%$ sequences had same ending position; thus we eliminated the $2.5 \%$ of sequences that ended before this position. Start positions were optimized to $85 \%$ sequence position equivalency, and sequences which started later were removed. Finally, columns in the alignments were filtered. The remaining 136,463 sequences were $206 \mathrm{bp}$ in average length. Sequences were pre-clustered and 2052 reads were detected and removed as pyrosequencing errors and chimeras by the uchime program (Edgar et al., 2011). Taxonomy information was assigned to sequences with a cutoff of 50\% (Claesson et al., 2009) by Naïve Bayesian classifier (Wang et al., 2007), with Ribosomal Database Project (RDP) references. Sequences with similarities higher than $97 \%$ were assigned to one OTU (operational taxonomic unit).

Samples were randomly resampled to 1498 reads for different calculations. The Good's coverage was calculated, which represents the ratio of OTUs that have been sampled once to the total number of sequences. The Chao 1 index was determined to estimate the richness of a sample based on the numbers of observed OTUs, singletons and doubletons. The inverse Simpson and Shannon indices were calculated to represent OTU diversity (alpha diversity) for each sample. The evenness values were used to evaluate the distribution evenness of relative OTU abundances. The beta diversity, which represents differentiation among each sample, was calculated and represented in two ways: a dendrogram which was calculated using the Jaccard index, then clustered using the UPGMA algorithm; and a principle coordinate analysis (PCoA) calculated using the Yue and Clayton index (Yue and Clayton, 2005). An ANOVA test was used to evaluate variability in diversity across sites.

\section{Kinetic Drive Evaluation}

A combined thermodynamic-kinetic rate law was used to evaluate factors controlling microbial metabolic rates in the CASS system (Jin and Bethke, 2003, 2005):

$$
v=\mathrm{k}[X] F_{T} F_{K}
$$

Metabolic rate $v$ is the product of the rate constant $k$, microbial biomass concentration $[X]$, thermodynamic factor $F_{T}$ and the kinetic factor $F_{K}$. The range of values for kinetic and thermodynamic factors lies between 1 and 0 . Larger factors (toward 1) represent less kinetic or thermodynamic limitations, or that the reaction is far from equilibrium and the forward direction overwhelms the reverse direction. If the reaction is close to equilibrium, the factors decrease toward to 0 , which means little energy is available for microorganisms. This rate law is built on Monod and Michaelis-Menten kinetics (Monod, 1949; Michaelis et al., 2011), and is extended to consider the reverse reactions and include a thermodynamic potential factor. The consideration of reverse reactions and thermodynamic factors can be neglected where the environments contain abundant energy such that the forward reaction overcomes the reverse direction (Jin and Bethke, 2007). Thus, the model can be used to test the assumption that organic carbon substrates are nonlimiting in the CASS environment under study.

Acetate is the most common organic substrate available for sulfate reduction in many environments (Lovley and Klug, 1982):

$$
\mathrm{SO}_{4}^{2-}+\mathrm{CH}_{3} \mathrm{COO}^{-} \leftrightarrow \mathrm{HS}^{-}+2 \mathrm{HCO}_{3}^{-}
$$

The thermodynamic factor $F_{T}$ of acetotrophic sulfate reduction is:

$$
F_{T}=1-\exp \left(\frac{\triangle G_{A}+\triangle G_{C}}{\chi R T}\right)
$$

where $R$ and $T$ are the gas constant $(8.314 \mathrm{~J} / \mathrm{Kmol})$ and absolute temperature ( $298 \mathrm{~K}$ was used in this study), $\chi$ is average stoichiometric number with a suggested value of 6 used in this study (Jin et al., 2013). $\triangle G_{C}$ is the energy conserved by SRB per mole of sulfate, which is estimated to be $33-47 \mathrm{~kJ} / \mathrm{mol}$ (Jin and Bethke, 2009) with a value of 45 used in this study (Jin et al., 2013). The energy available in the environment $\triangle G_{A}$ is the Gibbs free energy of reaction (Equation 8):

$$
\Delta G_{A}=\Delta G_{T}^{0}+R T \ln \frac{\gamma_{\mathrm{HS}^{-}}\left[\mathrm{HS}^{-}\right] \cdot \gamma_{\mathrm{HCO}_{3}^{-}}\left[\mathrm{HCO}_{3}^{-}\right]^{2}}{\gamma_{\mathrm{SO}_{4}^{2-}}\left[\mathrm{SO}_{4}^{2-}\right] \cdot \gamma_{\mathrm{CH}_{3} \mathrm{COO}^{-}}\left[\mathrm{CH}_{3} \mathrm{COO}^{-}\right]}
$$


where $\gamma_{i}$ is the activity coefficient, [i] is the concentration of reactant or product $i$, and the $\Delta G_{T}^{0}$ is the standard Gibbs free energy at absolute temperature, $\mathrm{T}^{\circ} \mathrm{K}$. The activity coefficient $\gamma_{i}$ used in this study was derived using the Geochemist's Workbench software (Bethke, 2007). The activity coefficient ranges for $\mathrm{SO}_{4}^{2-}, \mathrm{CH}_{3} \mathrm{COO}^{-}$, $\mathrm{HS}^{-}$, and $\mathrm{HCO}_{3}^{-}$are $0.1561-$ $0.16508,0.6825-0.6842,0.6395-0.6426$, and $0.6825-0.6842$, respectively. The value of $\triangle G_{T}^{0}$ is $-47.6(\mathrm{~kJ} / \mathrm{mole})$ for acetotrophic sulfate reduction (Thauer et al., 1977; Sawadogo et al., 2013). The $\mathrm{SO}_{4}^{2-}$ and $\mathrm{CH}_{3} \mathrm{COO}^{-}$concentration profiles were modified from previous research at the same study site (Figure 8, Supplementary Table 2), the sulfate concentration range was 3-45 mM, the acetate concentration range was 0$95 \mathrm{mM}$, the sulfide value used the theoretically highest amount $2 \mu \mathrm{M}$ since the sulfide concentration is below the detection limit (Supplementary Table 2) (Burton et al., 2011), and the bicarbonate concentrations used the highest values measured in the study site $1.6 \mathrm{mM}$ (Johnston et al., 2011b). Other chemical concentrations used data reported from the same study site (Supplementary Table 2) (Ward et al., 2014).

The kinetic factor, $F_{K}$, derived from Monod (Monod, 1949) and Michaelis-Menten kinetic equations:

$$
v=v_{\max } \frac{\left[\mathrm{SO}_{4}^{2-}\right]}{K_{\mathrm{SO}_{4}^{2-}}+\left[\mathrm{SO}_{4}^{2-}\right]} \frac{\left[\mathrm{CH}_{3} \mathrm{COO}^{-}\right]}{K_{\mathrm{CH}_{3} \mathrm{COO}^{-}}+\left[\mathrm{CH}_{3} \mathrm{COO}^{-}\right]}
$$

where $v_{\max }$ is the maximum metabolic rate, and the kinetic factor is described as:

$$
F_{K}=\frac{\left[\mathrm{SO}_{4}^{2-}\right]}{K_{\mathrm{SO}_{4}^{2-}}+\left[\mathrm{SO}_{4}^{2-}\right]} \frac{\left[\mathrm{CH}_{3} \mathrm{COO}^{-}\right]}{K_{\mathrm{CH}_{3} \mathrm{COO}^{-}}+\left[\mathrm{CH}_{3} \mathrm{COO}^{-}\right]}
$$

where $K$ is the half-saturation constant; this study used values of $5.0 \times 10^{-6} \mathrm{M}$ and $9.17 \times 10^{-4} \mathrm{M}$ as $K_{\mathrm{CH}_{3} \mathrm{COO}^{-}}$and $K_{\mathrm{SO}_{4}^{2-}}$, respectively (Jin et al., 2013).

\section{Plotting Software}

The software R (Statistical Package, 2009), R package gplots (Warnes et al., 2009), Microsoft Excel, iWork Numbers, and FigTree were used for generating plots.

\section{Results}

\section{In Situ Geochemical Measurements}

The $\mathrm{pH}$ of sediments generally decreased along the transect from the sea toward the upland site ("A1") for the upper portions $(0-10 \mathrm{~cm})$ of each core, with values from 3.29 to 6.13 at site A1, 4.38 to 5.92 at site $\mathrm{A} 2$, and 6.08 to 6.43 at site A3. In contrast, $\mathrm{pH}$ values were similar for all three sites for the lower portions $(10-20 \mathrm{~cm})$, ranging from 5.97 to 6.79 . The Eh values decreased with depth within each core (from 51 to $-127 \mathrm{mV}$ at site A1, 20 to $-207 \mathrm{mV}$ at site $\mathrm{A} 2$, and 10 to $-459 \mathrm{mV}$ at site A3), but generally increased along the transect from the sea toward the upland site at each depth.

\section{Organic Geochemistry Analyses}

The polar fractions from surface sediments of each transect site, as well as from the acidic control site, were dominated by a suite of plant-derived pentacyclic 3-oxy triterpenoids, including oleanolic, betulinic and ursolic acids, which showed a similar distribution in all samples. However, these compounds were absent in the polar fractions obtained from the mangrove control site, which was dominated by the triterpenoid taraxerol. In the aromatic fractions, pentacyclic triterpenoid derivatives were highly abundant (Figure 2). However, the aromatic fraction from the "Acidic Site" was dominated by a des-A-oleanane, whereas in the transect sites a des-A-lupane was the most abundant compound.

\section{DNA Sequences Analyses}

The 95\% confidence intervals of alpha diversity and richness were computed and the higher and lower boundaries were checked (Supplementary Table 2) to make sure the variations among samples were greater than the $95 \%$ confidence interval limitations. Average sampling coverage values showed significant increase along the transect moving away from the sea (72\% for site A3, $81 \%$ for site $\mathrm{A} 2$, and $88 \%$ for site $\mathrm{A} 1, P<0.001$, ANOVA). Chao richness estimates, which estimate the number of phylogenetically different OTUs (3\% or more different in sequence composition), displayed a significant decrease from site A3 to A1 $(P<0.001$, ANOVA), with the highest values in the upper part of site A3 (3668 reads), followed by sites A2 (1707 reads) and A1 (1128 reads), respectively. Both

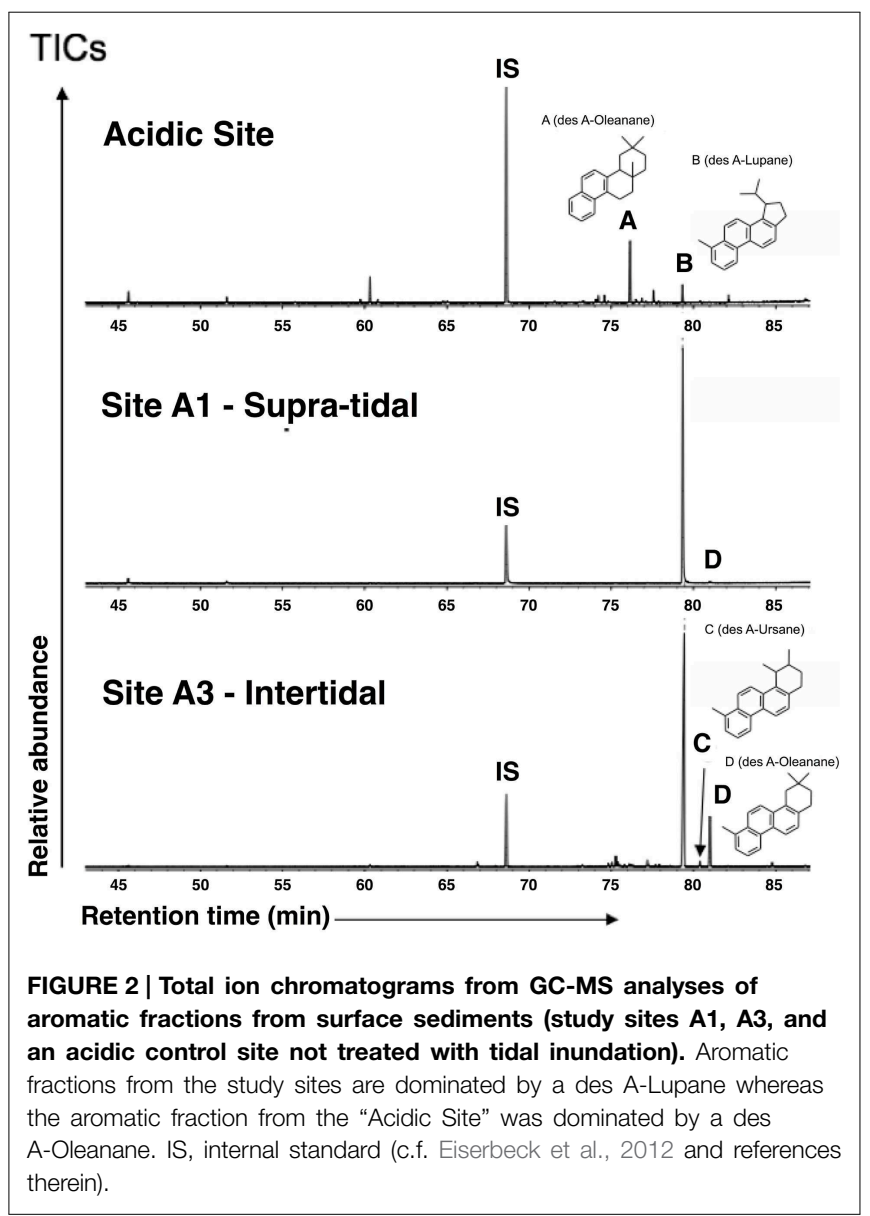




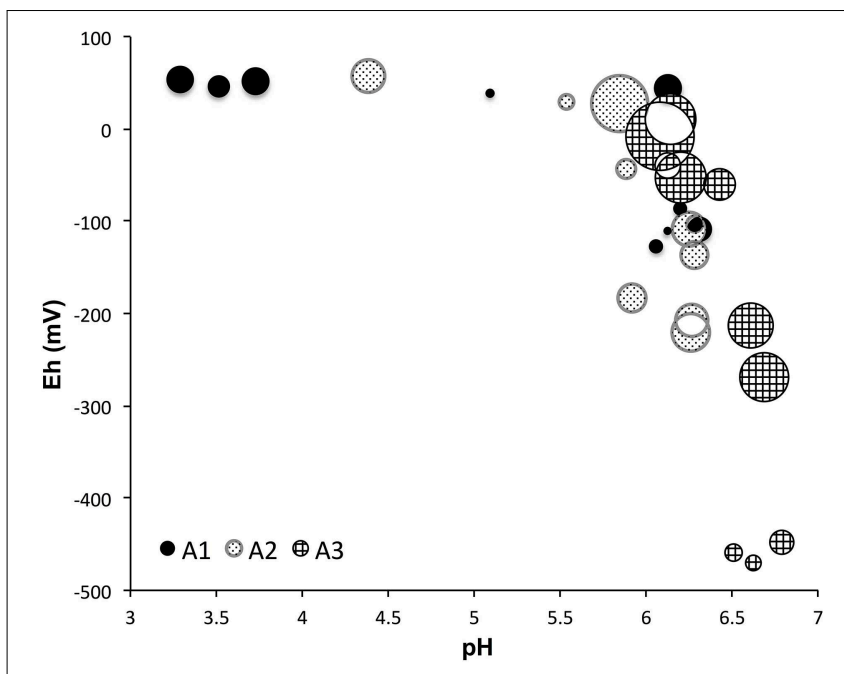

FIGURE 3 | The alpha diversity (inverse Simpson) vs. pH and Eh values among three sampling sites, the diversity values are proportional to the area of bubbles. The more positive Eh values indicate more oxidized environments. Diversity showed significant difference among three sites $(P<0.01$, ANOVA $)$

Shannon and Simpson diversity indices showed a significant difference among the three sites $(P<0.01$, ANOVA), which is shown on the $\mathrm{pH}$ and $\mathrm{Eh}$ diagram with the inverse Simpson index (Figure 3). The inverse Simpson index was in the range of 6-500 and Shannon index was in the range of 2.3-6.4 (Supplementary Table 2). Simpson's evenness indices were all below 0.37 , which indicates a relatively even microbial distribution.

Beta diversity analysis illustrated the degree of similarity in microbial composition for each site and sample (Figure 4). Sequences tended to group into clusters consistent with major physico-chemical changes in soil profile, as well as with variations in the degree of soil moisture saturation (Figure 1). Relative percentage representations of microbial community structure, separated into domain, phylum and class for each zone are shown in Figure 5. The inner, middle and outer circles represent domain, phylum and class levels, respectively (Figure 5).

Bacteria comprised $\sim 89 \%$ and archaea $\sim 11 \%$ of the prokaryotic community structure, taken across all sites within the East Trinity wetlands. In total 30 bacterial and three archaeal phyla (nanoarchaeota occupied only $0.04 \%$ and therefore did not show observable area in Figure 5) were identified. Proteobacteria was the most abundant phylum detected at any site, contributing $\sim 39 \%$ of the total $16 \mathrm{~S}$ rRNA gene sequences. The nine most abundant phyla recovered accounted for $\sim 93 \%$ of these sequences. The relative abundance of each shown class or phylum differed between zonations. For example, the abundance of deltaproteobacteria had the highest abundance at Zone 2 (19\%, compared to $13 \%$ at Zone 1 and $10 \%$ at Zone 3$)$. The gamma-, beta-, and alpha-proteobacteria exhibited higher sequence abundances at Zone 1 (38\% totally, compared to $30 \%$ at site Zone 2 and $12 \%$ at site Zone 3). The Chloroflexi, Bacteroidetes,

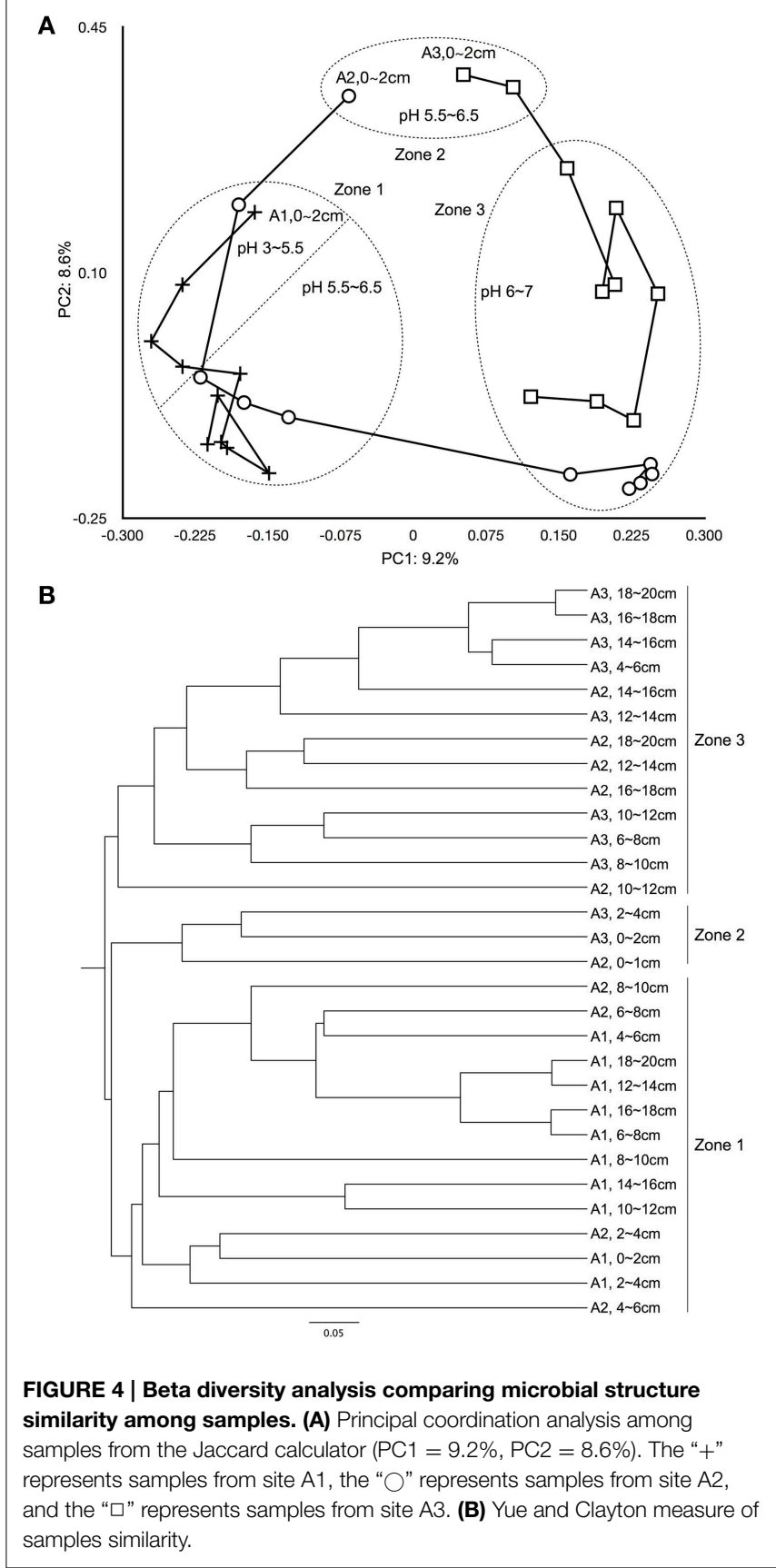

Firmicutes, Euryarcheota, and Crenarchaeota showed greater abundances in Zone 2 (22\%) and Zone 3 (39\%), compared to Zone 1 (8\%).

Classes delta-, gamma-, alpha-proteobacteria, and Acidobacteria were selected to compare their relative abundances among different zonations and other environments, such as marine sediments and AMD systems (Figure 6). Several genera, which have been reported by previous researchers to have iron reducing ability, were picked from this study to represent the abundance of IRB (Table 1). The iron-reducing bacterial reads were proportional to those of deltaproteobacteria, and iron-oxidizing bacterial reads were proportional to those of 


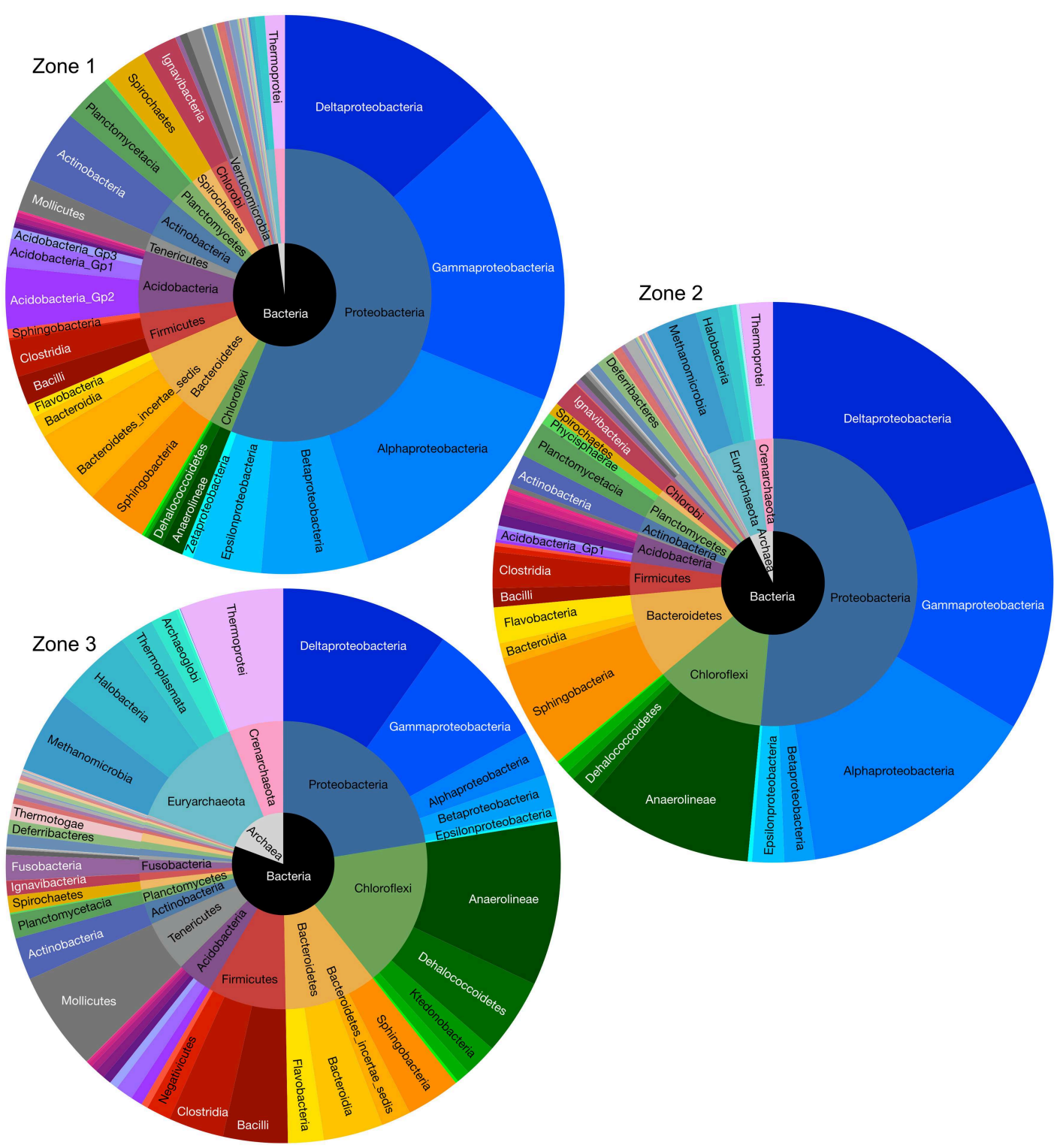

FIGURE 5 | Microbial abundance and compositions of Zone 1, Zone 2, and Zone 3 in kingdom (inner circle), phylum (middle circle), and class (outer lever) taxonomic levels.

sulfur-oxidizing bacteria, in the organic and sulfuric horizons (Figure 7). The kinetic drives of heterotrophic sulfate and iron reductions were calculated to be close to unity in the study area (top $20 \mathrm{~cm}$, Figure 8 and Supplementary Table 3), which supports the lack of kinetic inhibition for metabolisms in this CASS system.

\section{Discussion}

\section{Organic Source and Preservation}

There is more than $20 \%$ (by weight) organic carbon in the organic horizon at East Trinity wetlands (Hicks et al., 1999). This relatively high organic matter content most likely results from a mode of origin and preservation uniquely associated with reflooded CASS environments. Mangroves can slow surface water flow rates and reduce wave scour, which favors fine particle trapping and organic matter accumulation (Young and Harvey, 1996; Alongi, 2008). Sediments in mangrove swamps usually contain a large amount of organic matter (Kristensen et al., 2008). Mineralogy may play a role in preserving organic carbon in CASS systems; the oxidation of iron sulfides generates secondary iron minerals such as ferrihydrite and goethite in the study site (Hicks et al., 1999; Johnston et al., 2010), which have been shown to preserve mineral-bound organic carbon in subsoils (KogelKnabner et al., 2008). Environmental factors including salinity, soil $\mathrm{pH}$ or the tidal-inundation level at the sites control primary 

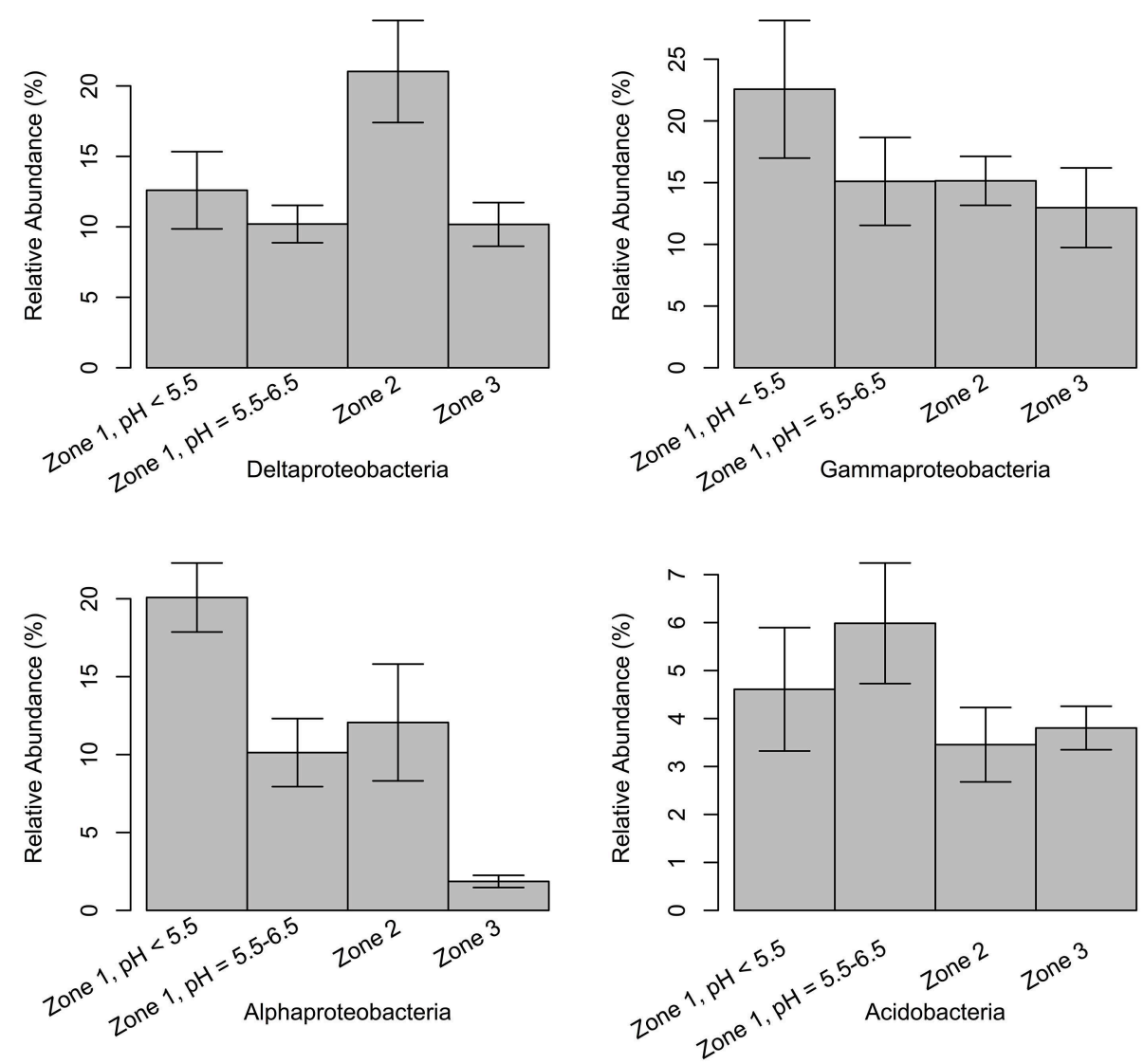

FIGURE 6 | Relative abundance of classes delta-, gamma-, alpha-proteobacteria, and Acidobacteria from Zone 1 to Zone 3. Samples in Zone 1 are separated into two parts based on

the $\mathrm{pH}$ values and structure similarity (Figure $\mathbf{3 A}$ ). The error bars show the 95\% higher and lower confidence intervals around mean values.

production; in particular the plant type will shape the types of organics available for microbial degradation.

Changes in plant types due to tidal inundation treatment contributed a large amount of organic matter input, while organo-mineral interactions resulted in unusual preservation of organic acids. Combined with invertebrate decay in the mangrove area, these factors contributed to the high abundance of organic matter in the system, and hence influenced microbial structures and distributions. In our wetland site, Melaleuca trees (mostly Melaleuca leucadendra) became the predominant plant species in the drained lands, but at locations with re-introduced tidal flows, such as our study site, they died off and the original mangrove vegetation (Avicennia marina, Aegiceras corniculatum, and Excoecaria agallocha, etc...) returned (Newton et al., 2014). There have been several reports of various pentacyclic triterpenoid acids in Melaleuca species (Lee, 1998; Lee and Chang, 1998, 1999; Abdel Bar et al., 2008), the ursolic and oleanolic acids have also been found in mangrove leaves (Ghosh et al., 1985). However, due to their high reactivity, the abundance of these compounds in sediments is rare. The suite of compounds in the polar fractions of sites $\mathrm{A} 1-\mathrm{A} 3$ and the "Acidic Site" presented here

may have been preserved by organo-mineral interactions with iron oxyhydroxides (Kogel-Knabner et al., 2008). Furthermore, previous research suggests that triterpenoids play an important role in salt adaptation for plants, and therefore the abundance of triterpenoids in mangrove species increases with salinity (Oku et al., 2003). Among the pentacyclic triterpenoids, betulin is more easily degraded and is thought to be a marker of mangrove Avicennia (Koch et al., 2005), which is widespread in the East Trinity study site (Department of Agriculture, Fisheries and Forestry, Queensland Government), consistent with our finding of abundant betulinic acid across our sites. Under reducing/anoxic conditions in sediments, pentacyclic triterpenoids are transformed by microbially-mediated A-ring degradation and progressive aromatization reactions during (early) diagenesis (e.g., Trendel et al., 1989; Le Métayer et al., 2005; Melendez et al., 2013; Schnell et al., 2014; Figure 2).

In addition to the type and abundance of organic matter, the existence of plants would also influence microbial distributions. In the rhizosphere area of treated wetlands, microbial diversity and activity are typically enhanced (Münch et al., 2005; Faulwetter et al., 2009). Phragmites australis, also called Common Reed, is distributed throughout the study site (Johns, 2010) with 
TABLE 1 | Genera of iron-reducing bacteria.

\begin{tabular}{ll}
\hline Genus name & References \\
\hline IRON-REDUCING & \\
\hline Paraferrimonas & Khan and Harayama, 2007 \\
Aciditerrimonas & Itoh et al., 2011 \\
Desulfuromonas & Coates et al., 1995 \\
Bacillus & Pollock et al., 2007 \\
Pelobacter & Lovley et al., 1995 \\
Desulfuromusa & Vandieken, 2006 \\
Desulfitobacterium & Finneran et al., 2002 \\
Thiobacillus & Temple and Colmer, 1951 \\
Geobacter & Lovley et al., 1993; Caccavo \\
& et al., 1994 \\
Desulfosporosinus & Robertson et al., 2001 \\
Ferroplasma & Golyshina et al., 2000 \\
Geothrix & Coates et al., 1999 \\
Shewanella & Roh et al., 2006 \\
Ferribacterium & Cummings et al., 1999 \\
Ferrimonas & Rosselló-Mora et al., 1995 \\
\hline & \\
\hline & \\
\hline
\end{tabular}

roots down to a depth of $20-30 \mathrm{~cm}$ (Stottmeister et al., 2003). It is reported that these roots improve nitrification and denitrification 20-50 $\mathrm{mm}$ away from the roots (Münch et al., 2005), and have a higher efficiency of transporting oxygen into the rhizosphere than diffusion alone (Armstrong and Armstrong, 1990). A higher redox potential gradient was observed from $\sim 500 \mathrm{mV}$ near root surface to $\sim-250 \mathrm{mV}$ in $1-20 \mathrm{~mm}$ from the roots (Faulwetter et al., 2009). The roots likely increased soil heterogeneity in the subsurface, which could enhance microbial diversity since aerobic or microaerophilic microorganisms could survive in niches throughout otherwise anaerobic zones (Lamers et al., 2012).

\section{Alpha Diversity Controlled by Organic Matter, pH, and Eh Values}

Much research has shown that pH (Fierer and Jackson, 2006; Hartman et al., 2008; Lauber et al., 2009), Eh (DeAngelis et al., 2010), and organic matter content and type (Zhou et al., 2002) have strong influences on microbial diversity. In this study, a large range of alpha diversity indices was observed in the East Trinity wetland (Supplementary Table 1). The highest diversity was observed at A3 $0-4 \mathrm{~cm}$, and is comparable to that of a coral ecosystem (Chen et al., 2010; Gaidos et al., 2010). The lowest diversity was observed at A1 $16-18 \mathrm{~cm}$ and is comparable with an AMD contaminated lake (Laplante and Derome, 2011). Both Eh and $\mathrm{pH}$ values led to differentiation of alpha diversity across the sampling sites.

Higher diversities were observed with more natural $\mathrm{pH}$ and higher Eh (more oxidizing) values (Figure 3). Site A1 contained much lower diversity (Supplementary Table 1, Supplementary Figure 1) when compared to sites A2 and A3, as a result of local $\mathrm{pH}$ and organic carbon content (Figure 8). The $0-8 \mathrm{~cm}$ depths of site A1 showed the lowest $\mathrm{pH}$ values (3-5) across all the samples, and site A1 contained the lowest organic carbon content among

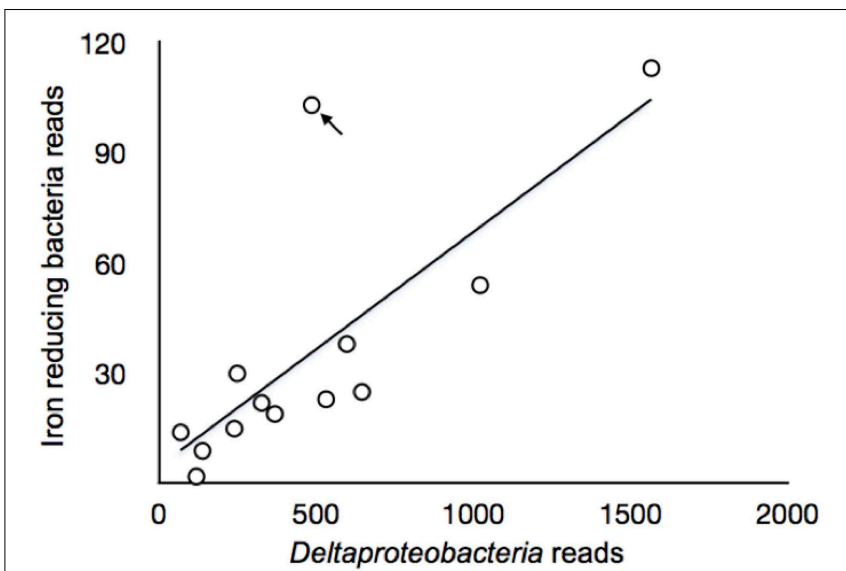

FIGURE 7 | Correlations between sequence reads of samples collected of sulfate-reducing deltaproteobacteria and iron reducing bacteria in Zone 3. The arrow points to the $A 34-6 \mathrm{~cm}$, where the sample differed from all other samples and was discussed in the text.

all 3 sites (Figure 8, Supplementary Table 1) (Burton et al., 2011). These conditions likely prevented colonization and growth by less acid-tolerant microbial groups. Site $\mathrm{A} 3$ showed $\mathrm{pH}>6$ for all depths (Figure 3), and microbial diversity decreased with depth in response to Eh (Supplementary Table 1, Supplementary Figure 1). For site A2, diversity appears to be influenced by both $\mathrm{pH}$ and Eh. From 0 to $10 \mathrm{~cm}$ depths in site A2, the diversity decreased with $\mathrm{Eh} / \mathrm{depth}$, and the $\mathrm{pH}$ (from 4 to $\sim 6$ ) did not show an effect on decreasing diversity. But for depths $10-20 \mathrm{~cm}$ in site A2, $\mathrm{pH}$ increased to $>6$, and the degree of diversity also increased, even though the environment was more reduced (i.e., deeper). Compared to site A1, which mostly experiences exposure to air, and site A3, which is mostly tidal-inundated, site A2 cut through two different soil layers (Figure 1A) and experiences the most oscillatory redox fluctuations, and also contained the highest amount of dissolved organic matter (Burton et al., 2011). The Eh values we measured represent the most oxidized potential since sediments were collected during the low tide period. The fluctuating redox potential results in higher diversity than would otherwise be present under more static chemical conditions (DeAngelis et al., 2010). Previous study of the same site showed sulfate reduction has the highest rate at site $\mathrm{A} 2$, which is controlled by dissolved organic matter content (Burton et al., 2011). The more neutral $\mathrm{pH}$, high organic matter content, and oscillatory redox fluctuations therefore likely resulted in the increased microbial diversity in site A2.

\section{Beta Diversity Shaped by Soil Layering, Water Saturation, and $\mathrm{pH}$}

The soil in the organic horizon contains high concentrations of organic carbon, while the sulfuric horizon contains the actual acid sulfate soil, and the sulfidic horizon consists of potential acid sulfate soils (Hicks et al., 1999). Both Jaccard and the Yue and Clayton indices showed that microbial community similarity changed spatially across the East Trinity field site (Figure 4). Based on principal coordinate scaling and hierarchical clustering, 

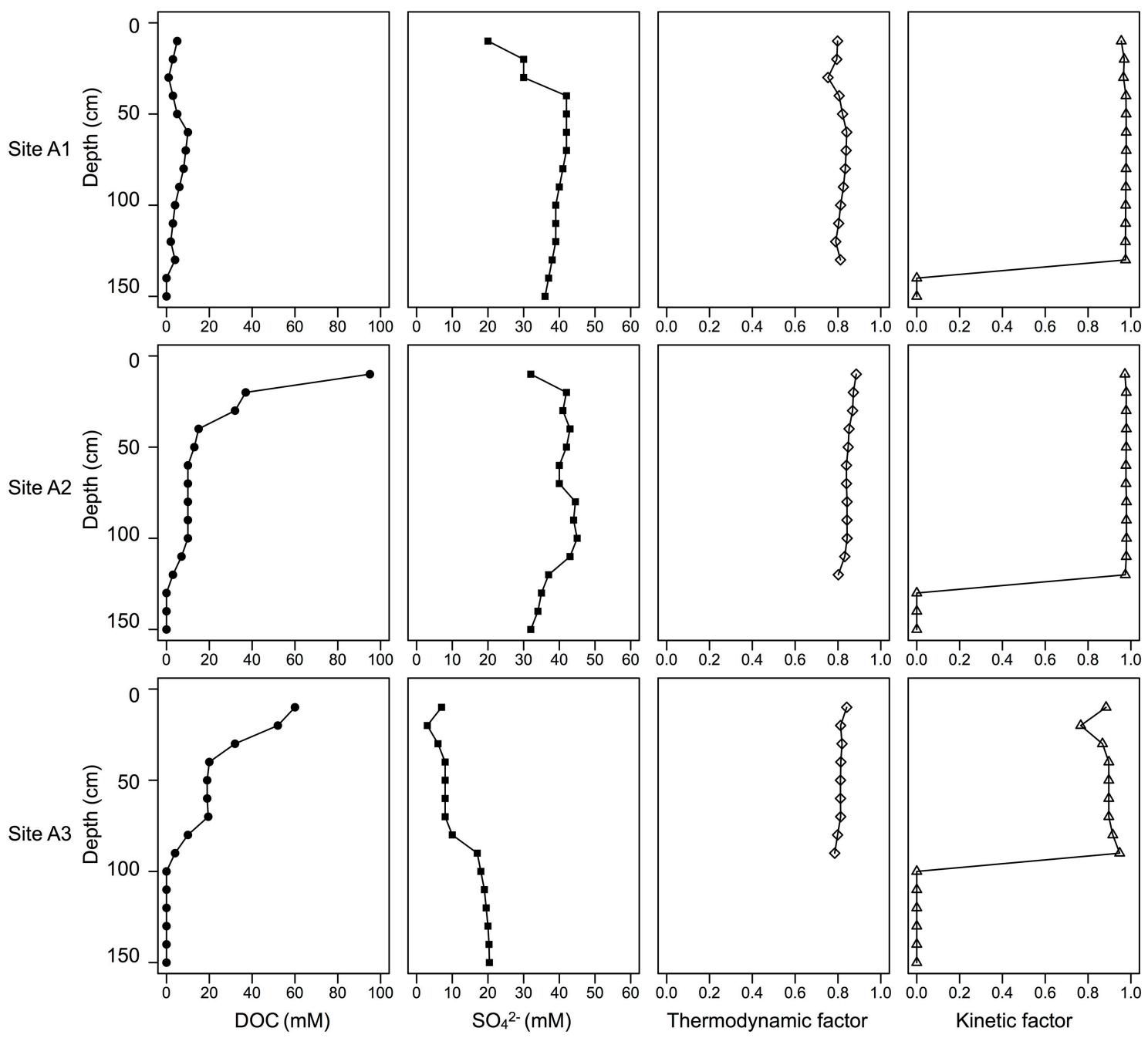

FIGURE 8 | Depth profile of $\mathrm{DOC}, \mathrm{SO}_{4}^{2-}$, labile $\mathrm{Fe}(\mathrm{III})$, crystalline $\mathrm{Fe}(\mathrm{III})$, soil density, and kinetic drives of heterotrophic sulfate and iron reductions. The values of $\mathrm{DOC}, \mathrm{SO}_{4}^{2-}$, labile $\mathrm{Fe}($ III), crystalline $\mathrm{Fe}(\mathrm{III})$, and soil density are modified from Burton et al. (2011).

three zones were distinguishable. Zone 1 included all of sites $\mathrm{A} 1$ and $\mathrm{A} 2$ from 2 to $10 \mathrm{~cm}$ in depth. Zone 2 consisted of site A3, 0-4 cm, and site A2, 0-2 cm, in depth. Site A2, depths 10$20 \mathrm{~cm}$, and site $A 3$, depths $4-20 \mathrm{~cm}$, made up Zone 3 . When we compare microbial diversity with in situ soil layering, water saturation, and $\mathrm{pH}$ values, the boundaries of these three zones were consistent with major variations in these environmental parameters (Figure 1). Zone 1 was located in the organic horizon; the upper part of Zone $1(\mathrm{~A} 1,0-8 \mathrm{~cm}$, and A2, $2-4 \mathrm{~cm})$ had the lowest $\mathrm{pH}$ values at 3.0-5.5, and the remaining lower part of Zone 1 had $\mathrm{pH}$ values between 5.5 and 6.5 (Figure 4A). Zone 2 experienced the most disturbance from tidal activity, with $\mathrm{pH}$ values between 5.5 and 6.5. Below the organic horizon is the sulfuric horizon, which hosts Zone 3 in which all samples had $\mathrm{pH}$ values $>6$ (Figure 4A), reflecting more than a decade of tidal inundation treatment (QASSIT, 2000). In this zone, the $\mathrm{pH}$ values have shown a increase from 3-4 to $3-8$ and pyrite has accumulated up to $30 \mu \mathrm{mol} / \mathrm{g}$ (Johnston et al., 2011a).

\section{Geochemical Parameters Influence Specific Functional Guilds}

Proteobacteria comprised the most abundant phylum at East Trinity (Figure 5). The most abundant classes (in decreasing order) were delta-, gamma-, alpha-, and beta-proteobacteria. This ordering differs from a more typical soil community structure, which exhibits the ordering alpha-, delta-, beta-, and then gamma-proteobacteria (Spain et al., 2009). The delta- and gamma- classes showed much higher abundances in East Trinity, suggesting marine and acidity influences. The deltaproteobacteria were more abundant in marine-influenced sediments [Figure 6, Zone 2, corresponding to the upper parts of sites A2 $(0-10 \mathrm{~cm})$ and A3 $(0-14 \mathrm{~cm})]$, which is consistent with seawater as a source of sulfate for bacterial sulfate reduction and the predominance of sulfate-reducing bacteria (SRB) within the delta class (Rabus et al., 2013). In these samples, $>45 \%$ of deltaproteobacteria were most closely related to members of order Desulfobacterales. The observed distribution of SRB at higher 
abundances in the upper depths at these sites also suggests a certain degree of oxygen tolerance to periods between tidal inundation (Canfield and Des Marais, 1991; Baumgartner et al., 2006), and/or possibly rapid changes in SRB activity with tidal fluctuation. The relative higher abundances of gamma- and alpha-proteobacteria in Zone 1 (Figure 6) are consistent with the microbial community composition observed in some AMD systems (Edwards et al., 2006; Brantner et al., 2014; Kamika and Momba, 2014), which are comparable to some CASS systems in terms of extreme acidification. Previous studies revealed that gamma-proteobacteria are more abundant at lower $\mathrm{pH}$ (Kuang et al., 2013; Fabisch et al., 2013). Acidobacteria (Lauber et al., 2009), which favors a low $\mathrm{pH}$ environment, was also present in relatively high abundance in Zone 1 but only in the higher $\mathrm{pH}$ area (Figure 6).

When the abundance of organic carbon exceeds the rate at which microorganisms can consume this resource (e.g., the maximum rate of enzymatic activity), microbes may not need to compete for electrons and carbon (Ling et al., 2012) and diversity can increase (Zhou et al., 2002). High organic matter can also increase soil aggregation by decreasing wetability (Chenu et al., 2000), which in turn further promotes physical heterogeneity and microbial diversity. The high concentration and multiple types of organic matter present at East Trinity could facilitate co-habitation of different metabolic guilds in close proximity within redox gradients throughout our sampling sites. For example, in Zone 1 (Figure 5), 49\% of beta-proteobacteria were derived from the genus Delftia (Figure 5), which is known to possess nitrate reduction ability (Wen et al., 1999; Shigematsu et al., 2003) and was isolated from biofilm of common reed $P$. australis (Borsodi et al., 2007), a plant species common to the study area (Johns, 2010). Roughly 64\% of epsilon-proteobacteria were closely related to Sulfurimonas, which possesses sulfur and thiosulfate oxidation abilities (Inagaki et al., 2003; Takai, 2006). Methanogenic Methanomicrobia showed increased abundance toward site A3 and deltaproteobacteria, typically associated with IRB and/or SRB, was a dominant class in all three sites. These metabolic guilds usually compete with each other for a limited energy source by maintaining the concentration of that source at the lowest threshold therefore establish a well resolved redox zonation which can be predicted thermodynamically (Hoehler et al., 1998).

The number of sequences representative of deltaproteobacteria was proportional (linear regression, $r^{2}=$ $0.59, p=0.002$ ) to those representing known iron-reducing bacteria or close relatives for Zone 3 (at the genus level, Table 1), which represents the sulfuric horizon (Figure 7). Zone 1 did not show this proportionality $\left(r^{2}=0.17, p=0.1427\right)$, and there are not enough samples in Zone 2 to demonstrate correlation convincingly. Site A3, depths $4-6 \mathrm{~cm}$, differed from all other samples and can be explained by the observation that the sulfuric horizon is much closer to the tidal zone in site A3 than in site A2 (Figure 7). We infer that high organic content allowed the two metabolic guilds effectively to co-exist in Zone 3 (Figure 8). The (re)precipitation of iron sulfide minerals will thermodynamically favor iron, sulfate and elemental sulfur reduction, by removing the products of these metabolic reactions. In addition, tidal activity can potentially drive reductive dissolution of crystalline iron(III) minerals (e.g., jarosite) from the lower soil profile, redistributing the iron as poorly crystalline iron(III) minerals in the upper organic horizon (Johnston et al., 2011a). These poorly crystalline iron(III) minerals can act as a relatively labile electron acceptor for iron-reducing bacteria. This observation suggests that microorganisms exhibit a relatively rapid response to tidally generated redox fluctuations.

To test the central hypothesis of this study, a thermodynamickinetic model was used to evaluate factors that control microbial metabolic rates. Microorganisms conserve energy from redox changes between the reactant and the product to form adenosine triphosphate (ATP). When the energy available in the environment is in excess of energy conserved by microbial metabolism, the thermodynamic factor moves toward a greater value, which means the reaction is far from equilibrium and the reaction has a greater tendency to move in the forward direction. Taking acetotrophic sulfate reduction as an example, the concentrations of sulfate and organic carbon (reactants) are higher than the concentrations of sulfide and bicarbonate (products) in the study site, and higher thermodynamic factors (0.75-0.89) were observed (Figure 8). In the study site, sulfide was removed by deposition of ironsulfide minerals and bicarbonate is removed by titrating acidity (Johnston et al., 2011b); both mechanisms favor sulfate reduction thermodynamically. In this situation, thermodynamic limitation can be ignored. The microbial metabolic rate law then becomes:

$$
v=k[X] \frac{\left[\mathrm{SO}_{4}^{2-}\right]}{K_{\mathrm{SO}_{4}^{2-}}+\left[\mathrm{SO}_{4}^{2-}\right]} \frac{\left[\mathrm{CH}_{3} \mathrm{COO}^{-}\right]}{K_{\mathrm{CH}_{3} \mathrm{COO}^{-}}+\left[\mathrm{CH}_{3} \mathrm{COO}^{-}\right]}
$$

In this case, the concentrations of sulfate and acetate were greater than the half-reaction constant $\mathrm{K}_{\mathrm{SO}_{4}^{2-}}$ and $\mathrm{K}_{\mathrm{CH}_{3} \mathrm{COO}^{-}}$ by at least one order of magnitude, and therefore the kinetic factor moves toward unity (Figure 8, Supplementary Table 2). This phenomenon was observed by Jin and Bethke (2003) for the initial stage of an incubation experiment when all substrates were present at high level. Both thermodynamic and kinetic factors showed high values in the study site, suggesting that the energy available was higher than the equilibrium state. The "snapshot" data used in this study support the hypothesis that organic matter content was higher than thermodynamic maintainance concentrations. Therefore, we infer that IRB and SRB did not need to compete for energy in the study site.

Microbial metabolic rates depend on a the rate constant $k$ and microbial biomass concentrations. Biomass in the thermodynamic-kinetic model and other kinetic models does not account for dormant microbial cells (Jin et al., 2013). However, dormancy has been reported to help maintain biodiversity (Jones and Lennon, 2010), and was suggested as a survival strategy in highly dynamic environments (Lennon and Jones, 2011).

\section{Microbial Ecology and CASS System Evaluation}

Microbial distributions in the East Trinity wetlands support the paradigm of community selection by from a homogenous population (De Wit and Bouvier, 2006), which is controlled by environmental heterogeneities (Bowen et al., 2009) associated 
with increased acid or salinity in this site. High concentrations and multiple types of organic matter would further increase similarity across samples. The low axis loading in our principal coordinate analysis (Figure 4A) confirmed that all sites were similar in terms of microbial community structure. Zones of similar dominant microbial guilds were defined across sites on the basis of environmental parameters such as $\mathrm{pH}$, Eh, soil layering, and water saturation. This research revealed that vertically stratified models linking redox zonation and microbial guild distribution are not useful for predicting biogeochemical cycling at East Trinity.

Tidal re-inundation is being tested as an effective means for natural remediation of CASS systems. However, tidal fluctuations can make CASS systems highly dynamic environments with respect to redox states and the flux of nutrients and electron donors or acceptors. Correspondingly, microbial communities living in tidal zones experience both static and fluctuating environmental conditions that, in turn, are modulated by lithological compositions and hydrological connectivity. For researchers attempting to construct complete biogeochemical process models, these factors must also be considered.

\section{References}

Abdel Bar, F. M., Zaghloul, A. M., Bachawal, S. V., Sylvester, P. W., Ahmad, K. F., and Sayed El, K. A. (2008). Antiproliferative triterpenes from Melaleuca ericifolia. J. Nat. Prod. 71, 1787-1790. doi: 10.1021/np8 00360a

Alongi, D. M. (2008). Mangrove forests: resilience, protection from tsunamis, and responses to global climate change. Estuar. Coast. Shelf Sci. 76, 1-13. doi: 10.1016/j.ecss.2007.08.024

Armstrong, J., and Armstrong, W. (1990). Light-enhanced convective throughflow increases oxygenation in rhizomes and rhizosphere of Phragmites australis (Cav.) Trin. ex Steud. New Phytol. 141, 121-128. doi: 10.1111/j.1469-8137.1990.tb00382.x

Åström, M., and Björklund, A. (1995). Impact of acid sulfate soils on stream water geochemistry in western Finland. J. Geochem. Explor. 55, 1-8. doi: 10.1016/0375-6742(95)00018-6

Baumgartner, L. K., Reid, R. P., Dupraz, C., Decho, A. W., Buckley, D. H., Spear, J. R., et al. (2006). Sulfate reducing bacteria in microbial mats: changing paradigms, new discoveries. Sediment. Geol. 185, 131-145. doi: 10.1016/j.sedgeo.2005.12.008

Bethke, C. (2007). Geochemical and Biogeochemical Reaction Modeling. New York, NY: Cambridge University Press. doi: 10.1017/cbo97805116 19670

Borsodi, A. K., Rusznyák, A., Molnár, P., Vladár, P., Reskóné, M. N., Tóth, E. M., et al. (2007). Metabolic activity and phylogenetic diversity of reed (Phragmites australis) periphyton bacterial communities in a hungarian shallow soda lake. Microb. Ecol. 53, 612-620. doi: 10.1007/s00248-006-9133-x

Bowen, J. L., Crump, B. C., Deegan, L. A., and Hobbie, J. E. (2009). Salt marsh sediment bacteria: their distribution and response to external nutrient inputs. ISME J. 3, 924-934. doi: 10.1038/ismej.2009.44

Brantner, J. S., Haake, Z. J., Burwick, J. E., Menge, C. M., Hotchkiss, S. T., and Senko, J. M. (2014). Depth-dependent geochemical and microbiological gradients in $\mathrm{Fe}$ (III) deposits resulting from coal mine-derived acid mine drainage. Front. Microbiol. 5:215. doi: 10.3389/fmicb.2014.00215

Bronswijk, J. J. B., Groenenberg, J. E., Ritsema, C. J., van Wijk, A. L. M., and Nugroho, K. (1995). Evaluation of water management strategies for acid sulphate soils using a simulation model: a case study in Indonesia. Agric. Water Manage. 27, 125-142. doi: 10.1016/0378-3774(95) 01135-6

\section{Acknowledgments}

The authors acknowledge funding from the Australian Research Council (LP110100732) and CRC CARE Project 4.1.16.12-13/A A National Demonstration Site for Acid Sulfate Soil Remediation. We thank Andrew Rose (Southern Cross GeoScience, Southern Cross University) and Andre $\mathrm{Mu}$ (School of Earth Sciences and Department of Microbiology and Immunology, University of Melbourne) for helpful advice and Steve Wilbraham (Department of Science, Information Technology, Innovation and the Arts, Queensland Government, Australia) for logistical and fieldwork support. Geoff Chidlow (Curtin University) is thanked for technical support with GC-MS analyses, and Lorenz Schwark (Kiel University) is thanked for assistance with selected compound identifications.

\section{Supplementary Material}

The Supplementary Material for this article can be found online at: http://journal.frontiersin.org/article/10.3389/fmicb. 2015.00624

Brosius, J., Dull, T. J., Sleeter, D. D., and Noller, H. F. (1981). Gene organization and primary structure of a ribosomal RNA operon from Escherichia coli. J. Mol. Biol. 148, 107-127. doi: 10.1016/0022-2836(81)9 0508-8

Burton, E. D., Bush, R. T., Johnston, S. G., and Sullivan, L. A. (2011). Sulfur biogeochemical cycling and novel Fe-S mineralization pathways in a tidally re-flooded wetland. Geochim. Cosmochim. Acta 75, 3434-3451. doi: 10.1016/j.gca.2011.03.020

Burton, E. D., Bush, R. T., Sullivan, L. A., Johnston, S. G., and Hocking, R. K. (2008). Mobility of arsenic and selected metals during re-flooding of iron- and organic-rich acid-sulfate soil. Chem. Geol. 253, 64-73. doi: 10.1016/j.chemgeo.2008.04.006

Caccavo, F., Lonergan, D. J., Lovley, D. R., Davis, M., Stolz, J. F., and McInerney, M. J. (1994). Geobacter sulfurreducens sp. nov., a hydrogen- and acetate-oxidizing dissimilatory metal-reducing microorganism. Appl. Environ. Microbiol. 60, 3752-3759.

Canfield, D., and Des Marais, D. (1991). Aerobic sulfate reduction in microbial mats. Science 251, 1471-1473. doi: 10.1126/science.11538266

Chapelle, F. H., and Lovley, D. R. (1992). Competitive exclusion of sulfate reduction by $\mathrm{Fe}(\mathrm{lll})$-reducing bacteria: a mechanism for producing discrete zones of high-iron ground water. Ground Water 30, 29-36. doi: 10.1111/j.17456584.1992.tb00808.x

Chen, C.-P., Tseng, C.-H., Chen, C. A., and Tang, S.-L. (2010). The dynamics of microbial partnerships in the coral Isopora palifera. ISME J. 5, 728-740. doi: 10.1038/ismej.2010.151

Chenu, C., Le Bissonnais, Y., and Arrouays, D. (2000). Organic matter influence on clay wettability and soil aggregate stability. Soil Sci. Soc. Am. J. 64, 1479-1486. doi: 10.2136/sssaj2000.6441479x

Claesson, M. J., O’Sullivan, O., Wang, Q., Nikkilä, J., Marchesi, J. R., Smidt, H., et al. (2009). Comparative analysis of pyrosequencing and a phylogenetic microarray for exploring microbial community structures in the human distal intestine. PLOS ONE 4:e6669. doi: 10.1371/journal.pone. 0006669

Coates, J. D., Ellis, D. J., Gaw, C. V., and Lovley, D. R. (1999). Geothrix fermentans gen. nov., sp. nov., a novel Fe(III)-reducing bacterium from a hydrocarbon-contaminated aquifer. Int. J. Syst. Bacteriol. 49(Pt 4), 1615-1622. doi: 10.1099/00207713-49-4-1615

Coates, J. D., Lonergan, D. J., Philips, E. J., Jenter, H., and Lovley, D. R. (1995). Desulfuromonas palmitatis sp. nov., a marine dissimilatory $\mathrm{Fe}(\mathrm{III})$ reducer 
that can oxidize long-chain fatty acids. Arch. Microbiol. 164, 406-413. doi: $10.1007 / \mathrm{BF} 02529738$

Crammond, N. (2002). The occurrence of thaumasite in modern construction - a review. Cement Concrete Comp. 24, 393-402. doi: 10.1016/S09589465(01)00092-0

Cummings, D. E., Caccavo, F. Jr., Spring, S., and Rosenzweig, R. F. (1999). Ferribacterium limneticum, gen. nov., sp. nov., an Fe(III)-reducing microorganism isolated from mining-impacted freshwater lake sediments. Arch. Microbiol. 171, 183-188. doi: 10.1007/s002030050697

De Wit, R., and Bouvier, T. (2006). "Everything is everywhere, but, the environment selects;" what did Baas Becking and Beijerinck really say? Environ. Microbiol. 8, 755-758. doi: 10.1111/j.1462-2920.2006.01017.x

DeAngelis, K. M., Silver, W. L., Thompson, A. W., and Firestone, M. K. (2010). Microbial communities acclimate to recurring changes in soil redox potential status. Environ. Microbiol. 12, 3137-3149. doi: 10.1111/j.14622920.2010.02286.x

Denmead, O. T., Macdonald, B. C. T., Bryant, G., White, I., Wang, W., Moody, P., et al. (2007). "Greenhouse gas emissions from sugarcane soils and nitrogen fertiliser management: II," in Proceedings of the 2006 Conference of the Australian Society of Sugar Cane Technologists held at Mackay, Queensland, Australia, 2-5 May 2006, 252-260 27, 97-105.

Dent, D. (1986). Acid Sulphate Soils: a Baseline for Research and Development. Wageningen: ILRI Publications.

Dent, D., and Pons, L. (1995). A world perspective on acid sulphate soils. Geoderma 67, 263-276. doi: 10.1016/0016-7061(95)00013-E

Edgar, R. C., Haas, B. J., Clemente, J. C., Quince, C., and Knight, R. (2011). UCHIME improves sensitivity and speed of chimera detection. Bioinformatics 27, 2194-2200. doi: 10.1093/bioinformatics/btr381

Edwards, R. A., Rodriguez-Brito, B., Wegley, L., Haynes, M., Breitbart, M., Peterson, D. M., et al. (2006). Using pyrosequencing to shed light on deep mine microbial ecology. BMC Genomics 7:57. doi: 10.1186/1471-2164-7-57

Eiserbeck, C., Nelson, R. K., Grice, K., and Curiale, J. (2012). Comparison of GCMS, GC-MRM-MS, and GC $\times$ GC to characterise higher plant biomarkers in Tertiary oils and rock extracts. Geochim. Cosmochim. Acta 87, 299-322. doi: 10.1016/j.gca.2012.03.033

Fabisch, M., Beulig, F., Akob, D. M., and Küsel, K. (2013). Surprising abundance of Gallionella-related iron oxidizers in creek sediments at $\mathrm{pH} 4.4$ or at high heavy metal concentrations. Front. Microbiol. 4:390. doi: 10.3389/fmicb.2013.00390.

Faulwetter, J. L., Gagnon, V., Sundberg, C., Chazarenc, F., Burr, M. D., Brisson, J., et al. (2009). Microbial processes influencing performance of treatment wetlands: a review. Ecol. Eng. 35, 987-1004. doi: 10.1016/j.ecoleng.2008.12.030

Fierer, N., and Jackson, R. B. (2006). The diversity and biogeography of soil bacterial communities. Proc. Natl. Acad. Sci. U.S.A. 103, 626-631. doi: 10.1073/pnas.0507535103

Finneran, K. T., Forbush, H. M., VanPraagh, C. V. G., and Lovley, D. R. (2002). Desulfitobacterium metallireducens sp. nov., an anaerobic bacterium that couples growth to the reduction of metals and humic acids as well as chlorinated compounds. Int. J. Syst. Evol. Microbiol. 52, 1929-1935. doi: 10.1099/ijs.0.02121-0

Fitzpatrick, R. W. (2003). "Overview of acid sulfate soil properties, environmental hazards, risk mapping and policy development in Australia," in Advances in Regolith Proceedings of the CRC LEME Regional Regolith Symposia (Bentley, WA: CRC LEME).

Gaidos, E., Rusch, A., and Ilardo, M. (2010). Ribosomal tag pyrosequencing of DNA and RNA from benthic coral reef microbiota: community spatial structure, rare members and nitrogen-cycling guilds. Environ. Microbiol. 13, 1138-1152. doi: 10.1111/j.1462-2920.2010.02392.x

Ghosh, A., Misra, S., Dutta, A. K., and Choudhury, A. (1985). Pentacyclic triterpenoids and sterols from seven species of mangrove. Phytochemistry 24, 1725-1727. doi: 10.1016/S0031-9422(00)82541-8

Golyshina, O. V., Pivovarova, T. A., Karavaiko, G. I., Kondratéva, T. F., Moore, E. R., Abraham, W. R., et al. (2000). Ferroplasma acidiphilum gen. nov., sp. nov., an acidophilic, autotrophic, ferrous-iron-oxidizing, cell-wall-lacking, mesophilic member of the Ferroplasmaceae fam. nov., comprising a distinct lineage of the Archaea. Int. J. Syst. Evol. Microbiol. 50(Pt 3), 997-1006. doi: 10.1099/00207713-50-3-997

Hartman, W. H., Richardson, C. J., Vilgalys, R., and Bruland, G. L. (2008). Environmental and anthropogenic controls over bacterial communities in wetland soils. Proc. Natl. Acad. Sci. U.S.A. 105, 17842-17847. doi: 10.1073/pnas.0808254105

Hicks, W., Bowman, G., and Fitzaptrick, R. W. (1999). East Trinity Acid Sulfate Soils: Part 1: Environmental Hazards. Adelaide: CSIRO Publishing.

Hoehler, T. M., Alperin, M. J., Albert, D. B., and Martens, C. S. (1998). Thermodynamic control on hydrogen concentrations in anoxic sediments. Geochim. Cosmochim. Acta 62, 1745-1756. doi: 10.1016/S0016-7037(98)0 0106-9

Inagaki, F., Takai, K., Kobayashi, H., Nealson, K. H., and Horikoshi, K. (2003). Sulfurimonas autotrophica gen. nov., sp. nov., a novel sulfur-oxidizing epsilonproteobacterium isolated from hydrothermal sediments in the Mid-Okinawa Trough. Int. J. Syst. Evol. Microbiol. 53, 1801-1805. doi: 10.1099/ijs.0.02682-0

Itoh, T., Yamanoi, K., Kudo, T., Ohkuma, M., and Takashina, T. (2011). Aciditerrimonas ferrireducens gen. nov., sp. nov., an iron-reducing thermoacidophilic actinobacterium isolated from a solfataric field. Int. J. Syst. Evol. Microbiol. 61, 1281-1285. doi: 10.1099/ijs.0.023044-0

Jin, Q., and Bethke, C. M. (2003). A new rate law describing microbial respiration. Appl. Environ. Microbiol. 69, 2340-2348. doi: 10.1128/AEM.69.4.23402348.2003

Jin, Q., and Bethke, C. M. (2005). Predicting the rate of microbial respiration in geochemical environments. Geochim. Cosmochim. Acta 69, 1133-1143. doi: 10.1016/j.gca.2004.08.010

Jin, Q., and Bethke, C. M. (2007). The thermodynamics and kinetics of microbial metabolism. Am. J. Sci. 307, 643-677. doi: 10.2475/04.2007.01

Jin, Q., and Bethke, C. M. (2009). Cellular energy conservation and the rate of microbial sulfate reduction. Geology 37, 1027-1030. doi: 10.1130/G30185A.1

Jin, Q., Roden, E. E., and Giska, J. R. (2013). Geomicrobial kinetics: extrapolating laboratory studies to natural environments. Geomicrobiol. J. 30, 173-185. doi: $10.1080 / 01490451.2011 .653084$

Johns, L. (2010). Field Guide to Common Saltmarsh Plants of Queensland. City East: Department of Employment, Economic Development and Innovation.

Johnston, S., Keene, A., and Bush, R. (2009b). "Remediation of coastal acid sulfate soils by tidal inundation: effectiveness and geochemical implications," in Proceedings of 18th NSW Coastal Conference, Ballina, NSW, 3-6 November, East Coast Conferences (Coffs Harbour, NSW).

Johnston, S. G., Bush, R. T., Sullivan, L. A., Burton, E. D., Smith, D., Martens, M. A., et al. (2009a). Changes in water quality following tidal inundation of coastal lowland acid sulfate soil landscapes. Estuar. Coastal Self Sci. 81, 257-266. doi: 10.1016/j.ecss.2008.11.002

Johnston, S. G., Keene, A. F., Burton, E. D., Bush, R. T., and Sullivan, L. A. (2012). Quantifying alkalinity generating processes in a tidally remediating acidic wetland. Chem. Geol. 304-305, 106-116. doi: 10.1016/j.chemgeo.2012.02.008

Johnston, S. G., Keene, A. F., Burton, E. D., Bush, R. T., Sullivan, L. A., McElnea, A., et al. (2010). Arsenic mobilization in a seawater inundated acid sulfate soil. Environ. Sci. Technol. 44, 1968-1973. doi: 10.1021/es903114z

Johnston, S. G., Keene, A. F., Bush, R. T., Burton, E. D., Sullivan, L. A., Isaacson, L., et al. (2011a). Iron geochemical zonation in a tidally inundated acid sulfate soil wetland. Chem. Geol. 280, 257-270. doi: 10.1016/j.chemgeo.2010.11.014

Johnston, S. G., Keene, A. F., Bush, R. T., Sullivan, L. A., and Wong, V. N. L. (2011b). Tidally driven water column hydro-geochemistry in a remediating acidic wetland. J. Hydrol. 409, 128-139. doi: 10.1016/j.jhydrol.2011.08.010

Jones, S. E., and Lennon, J. T. (2010). Dormancy contributes to the maintenance of microbial diversity. Proc. Natl. Acad. Sci. U.S.A. 107, 5881-5886. doi: 10.1073/pnas. 0912765107

Kamika, I., and Momba, M. N. B. (2014). Microbial diversity of Emalahleni mine water in South Africa and tolerance ability of the predominant organism to vanadium and nickel. PLoS ONE 9:e86189. doi: 10.1371/journal.pone.0086189

Khan, S. T., and Harayama, S. (2007). Paraferrimonas sedimenticola gen. nov., sp. nov., a marine bacterium of the family Ferrimonadaceae. Int. J. Syst. Evol. Microbiol. 57, 1493-1498. doi: 10.1099/ijs.0.64529-0

Koch, B. P., Harder, J., Lara, R. J., and Kattner, G. (2005). The effect of selective microbial degradation on the composition of mangrove derived pentacyclic triterpenols in surface sediments. Org. Geochem. 36, 273-285. doi: 10.1016/j.orggeochem.2004.07.019

Kogel-Knabner, I., Guggenberge, G., Kleber, M., Kandeler, E., Kalbitz, K., Scheu, S., et al. (2008). Organo-mineral associations in temperate soils: integrating biology, mineralogy, and organic matter chemistry. J. Plant Nutr. Soil Sci. 171, 61-82. doi: $10.1002 /$ jpln.200700048 
Kristensen, E., Bouillon, S., Dittmar, T., and Marchand, C. (2008). Organic carbon dynamics in mangrove ecosystems: a review. Aquat. Bot. 89, 201-219. doi: 10.1016/j.aquabot.2007.12.005

Kuang, J.-L., Huang, L.-N., Chen, L.-X., Hua, Z.-S., Li, S.-J., Hu, M., et al. (2013). Contemporary environmental variation determines microbial diversity patterns in acid mine drainage. ISME J. 7, 1038-1050. doi: 10.1038/ismej.2012.139

Lamers, L. P., van Diggelen, J. M., Op den Camp, H. J., Visser, E. J., Lucassen, E. C., Vile, M. A., et al. (2012). Microbial transformations of nitrogen, sulfur, and iron dictate vegetation composition in wetlands: a review. Front. Microbiol. 3:156. doi: $10.3389 /$ fmicb.2012.00156

Laplante, K., and Derome, N. (2011). Parallel changes in the taxonomical structure of bacterial communities exposed to a similar environmental disturbance. Ecol. Evol. 1, 489-501. doi: 10.1002/ece3.37

Lauber, C. L., Hamady, M., Knight, R., and Fierer, N. (2009). Pyrosequencingbased assessment of soil $\mathrm{pH}$ as a predictor of soil bacterial community structure at the continental scale. Appl. Environ. Microbiol. 75, 5111-5120. doi: 10.1128/AEM.00335-09

Le Métayer, P., Schaeffer, P., Duringer, P., and Roussé, S. (2005). 4, 4'Dimethyldinaphtho [a, d] cycloheptane, a naturally occurring polyaromatic derivative related to triterpenoids of the serratane series. Org. Lett. 7 , 3041-3044. doi: 10.1021/ol0509944

Lee, C., and Chang, M. (1998). A new norlupene from the leaves of Melaleuca leucadendron. J. Nat. Prod. 61, 375-376. doi: 10.1021/np9606052

Lee, C., and Chang, M. (1999). Four new triterpenes from the heartwood of Melaleuca leucadendron. J. Nat. Prod. 62, 1003-1005. doi: 10.1021/np980169e

Lee, C. K. (1998). Ursane triterpenoids from leaves of Melaleuca leucadendron. Phytochemistry 49, 1119-1122. doi: 10.1016/S0031-9422(97)01061-3

Lennon, J. T., and Jones, S. E. (2011). Microbial seed banks: the ecological and evolutionary implications of dormancy. Nat. Rev. Microbiol. 9, 119-130. doi: 10.1038/nrmicro2504

Ling, Y. C., Chen, Y. J., Sun, C. H., Cheng, T. W., and Wang, P. L. (2012). Potential of microbial methane formation in a high-temperature hydrocarbon seep. Appl. Geochem. 27, 1666-1678. doi: 10.1016/j.apgeochem.2012.04.002

Ljung, K., Maley, F., Cook, A., and Weinstein, P. (2009). Acid sulfate soils and human health-A millennium ecosystem assessment. Environ. Sci. Technol. 35, 1234-1242. doi: 10.1016/j.envint.2009.07.002

Lovley, D. R., and Klug, M. J. (1982). Intermediary metabolism of organic matter in the sediments of a eutrophic lake. Appl. Environ. Microbiol. 43, 552-560.

Lovley, D. R., and Phillips, E. J. (1987). Competitive mechanisms for inhibition of sulfate reduction and methane production in the zone of ferric iron reduction in sediments. Appl. Environ. Microbiol. 53, 2636-2641.

Lovley, D. R., Giovannoni, S. J., White, D. C., Champine, J. E., Phillips, E. J., Gorby, Y. A., et al. (1993). Geobacter metallireducens gen. nov. sp. nov., a microorganism capable of coupling the complete oxidation of organic compounds to the reduction of iron and other metals. Arch. Microbiol. 159, 336-344. doi: 10.1007/BF00290916

Lovley, D. R., Phillips, E. J., Lonergan, D. J., and Widman, P. K. (1995). Fe(III) and S0 reduction by Pelobacter carbinolicus. Appl. Environ. Microbiol. 61, 2132-2138.

Macdonald, B., Denmead, O. T., and White, I. (2004). Natural sulfur dioxide emissions from sulfuric soils. Atmos. Environ. 38, 1473-1480. doi: 10.1016/j.atmosenv.2003.12.005

Melendez, I., Grice, K., and Schwark, L. (2013). Exceptional preservation of Palaeozoic steroids in a diagenetic continuum. Sci. Rep. 3:2768. doi: $10.1038 /$ srep02768

Michaelis, L., Menten, M. L., Johnson, K. A., and Goody, R. S. (2011). The original michaelis constant: translation of the 1913 Michaelis-Menten paper. Biochemistry 50, 8264-8269. doi: 10.1021/bi201284u

Monod, J. (1949). The growth of microbial cultures. Annu. Rev. Microbiol. 3, 371-394. doi: 10.1146/annurev.mi.03.100149.002103

Moreau, J. W., Fournelle, J. H., and Banfield, J. F. (2013). Quantifying heavy metals sequestration by sulfate-reducing bacteria in an Acid mine drainage-contaminated natural wetland. Front. Microbiol. 4:43. doi: 10.3389/fmicb.2013.00043

Münch, C., Kuschk, P., and Röske, I. (2005). Root stimulated nitrogen removal: only a local effect or important for water treatment? Water Sci. Technol. 51, 185-192.
Nabbefeld, B., Grice, K., Twitchett, R. J., Summons, R. E., Hays, L., Bottcher, M. E., et al. (2010). An integrated biomarker, isotopic and palaeoenvironmental study through the Late Permian event at Lusitaniadalen, Spitsbergen. Earth Planet Sci. Lett. 291, 84-96. doi: 10.1016/j.epsl.2009.12.053

Newton, R. M., Addicott, P. E., and Bannink, P. (2014). Vegetation Survey of the East Trinity Reclamation Site. Brisbane, QLD: Queensland Herbarium, Queensland Department of Science, Information Technology, Innovation and the Arts.

Ohba, H., and Owa, N. (2005). Vertical distribution of physico-chemical properties and number of sulfur-oxidizing bacteria in the buried layer of soil profiles with marine-reduced sulfur compounds. Soil Sci. Plant Nutr. 51, 379-388. doi: 10.1111/j.1747-0765.2005.tb00043.x

Oku, H., Baba, S., Koga, H., Takara, K., and Iwasaki, H. (2003). Lipid composition of mangrove and its relevance to salt tolerance. J. Plant Res. 116, 37-45. doi: 10.1007/s10265-002-0069-z

Pollock, J., Weber, K. A., Lack, J., Achenbach, L. A., Mormile, M. R., and Coates, J. D. (2007). Alkaline iron(III) reduction by a novel alkaliphilic, halotolerant, Bacillus sp. isolated from salt flat sediments of Soap Lake. Appl. Microbiol. Biotechnol. 77, 927-934. doi: 10.1007/s00253-007-1220-5

Powell, B., and Martens, M. (2005). A review of acid sulfate soil impacts, actions and policies that impact on water quality in Great Barrier Reef catchments, including a case study on remediation at East Trinity. Mar. Pollut. Bull. 51, 149-164. doi: 10.1016/j.marpolbul.2004.10.047

QASSIT, Q. A. S. S. I. T. (2000). East Trinity Property Acid Sulfate Soils Remediation Action Plan. Indooroopilly: Queensland Government.

Rabus, R., Hansen, T. A., and Widdel, F. (2013). "Dissimilatory sulfate- and sulfurreducing prokaryotes," in The Prokaryotes, eds E. Rosenberg, E. F. DeLong, S. Lory, E. Stackebrandt, and F. Thompson (Berlin; Heidelberg: Springer), 309-404.

Robertson, W. J., Bowman, J. P., Franzmann, P. D., and Mee, B. J. (2001). Desulfosporosinus meridiei sp. nov., a spore-forming sulfate-reducing bacterium isolated from gasolene-contaminated groundwater. Int. J. Syst. Evol. Microbiol. 51, 133-140.

Roh, Y., Gao, H., Vali, H., Kennedy, D. W., Yang, Z. K., Gao, W., et al. (2006). Metal reduction and iron biomineralization by a psychrotolerant $\mathrm{Fe}(\mathrm{III})$-reducing bacterium, Shewanella sp. strain PV-4. Appl. Environ. Microbiol. 72, 3236-3244. doi: 10.1128/AEM.72.5.3236-3244.2006

Rosicky, M. A., Sullivan, L. A., Slavich, P. G., and Hughes, M. (2004), Factors contributing to the acid sulfate soil scalding process in the coastal floodplains of New South Wales, Australia. Aust. J. Soil Res. 42, 587-594. doi: 10.1071/SR03076

Rosselló-Mora, R. A., Ludwig, W., and Kampfer, P. (1995). Ferrimonas balearica gen. nov., spec. nov., a New Marine Facultative Fe(III)-reducing Bacterium. Syst. Appl. Microbiol. 18, 196-202. doi: 10.1016/S0723-2020(11)80390-5

Sammut, J., White, I., and Melville, M. D. (1996). Acidification of an estuarine tributary in eastern Australia due to drainage of acid sulfate soils. Mar. Freshwater Res. 47, 669-684. doi: 10.1071/MF9960669

Sawadogo, J. B., Traoré, A. S., and Dianou, D. (2013). Relationships between methanogens and sulfate-reducing bacteria during acetate, formate and lactate metabolism in Macrotermes bellicosus Termite Gut. World Appl. Sci. J. 24, 154-162. doi: 10.5829/idosi.wasj.2013.24.02.2215

Schloss, P. D. (2010). The effects of alignment quality, distance calculation method, sequence filtering, and region on the analysis of $16 \mathrm{~S}$ rRNA gene-based studies. PLoS Comput. Biol. 6:e1000844. doi: 10.1371/journal.pcbi.1000844

Schloss, P. D., Gevers, D., and Westcott, S. L. (2011). Reducing the effects of PCR amplification and sequencing artifacts on $16 \mathrm{~S}$ rRNA-based studies. PLoS ONE 6:e27310. doi: 10.1371/journal.pone.0027310

Schloss, P. D., Westcott, S. L., Ryabin, T., Hall, J. R., Hartmann, M., Hollister, E. B., et al. (2009). Introducing mothur: open-source, platformindependent, community-supported software for describing and comparing microbial communities. Appl. Environ. Microbiol. 75, 7537-7541. doi: 10.1128/AEM.01541-09

Schnell, G., Schaeffer, P., Tardivon, H., and Motsch, E. (2014). Contrasting diagenetic pathways of higher plant triterpenoids in buried wood as a function of tree species. Org. Geochem. 66, 107-124. doi: 10.1016/j.orggeochem.2013.11.001

Shigematsu, T., Yumihara, K., Ueda, Y., Numaguchi, M., Morimura, S., and Kida, K. (2003). Delftia tsuruhatensis sp. nov., a terephthalate-assimilating bacterium 
isolated from activated sludge. Int. J. Syst. Evol. Microbiol. 53, 1479-1483. doi: 10.1099/ijs.0.02285-0

Simek, M., Virtanen, S., Simojoki, A., Chroòáková, A., Elhottová, D., Krištùfek, V., et al. (2013). The microbial communities and potential greenhouse gas production in boreal acid sulphate, non-acid sulphate, and reedy sulphidic soils. Sci. Total Environ. 466C-467C, 663-672.

Spain, A. M., Krumholz, L. R., and Elshahed, M. S. (2009). Abundance, composition, diversity and novelty of soil Proteobacteria. ISME J. 3, 992-1000. doi: 10.1038 /ismej.2009.43

Statistical Package, R. (2009). R: A Language and Environment for Statistical Computing. Vienna: R Foundation for Statistical Computing.

Stephens, F. J., and Ingram, M. (2006). Two cases of fish mortality in low pH, aluminium rich water. J. Fish Dis. 29, 765-770. doi: 10.1111/j.13652761.2006.00772.x

Stottmeister, U., Wießner, A., Kuschk, P., Kappelmeyer, U., Kästner, M., Bederski, O., et al. (2003). Effects of plants and microorganisms in constructed wetlands for wastewater treatment. Biotechnol. Adv. 22, 93-117. doi: 10.1016/j.biotechadv.2003.08.010

Takai, K. (2006). Sulfurimonas paralvinellae sp. nov., a novel mesophilic, hydrogen- and sulfur-oxidizing chemolithoautotroph within the Epsilonproteobacteria isolated from a deep-sea hydrothermal vent polychaete nest, reclassification of Thiomicrospira denitrificans as Sulfurimonas denitrificans comb. nov. and emended description of the genus Sulfurimonas. Int. J. Syst. Evol. Microbiol. 56, 1725-1733. doi: 10.1099/ijs.0.64255-0

Temple, K. L., and Colmer, A. R. (1951). The autotrophic oxidation of iron by a new bacterium, thiobacillus ferrooxidans. J. Bacteriol. 62, 605-611.

Thauer, R. K., Jungermann, K., and Decker, K. (1977). Energy conservation in chemotrophic anaerobic bacteria. Bacteriol. Rev. 41, 100-180.

Trendel, J. M., Lohmann, F., Kintzinger, J. P., Albrecht, P., Chiarone, A., Riche, C., et al. (1989). Identification of des-A-triterpenoid hydrocarbons occurring in surface sediments. Tetrahedron 45, 4457-4470. doi: 10.1016/S00404020(01)89081-5

Van Breemen, N. (1973). Dissolved aluminum in acid sulfate soils and in acid mine waters. Soil Sci. Soc. Am. J. 37, 694-697. doi: 10.2136/sssaj1973.03615995003700050020x

Vandieken, V. (2006). Desulfuromonas svalbardensis sp. nov. and Desulfuromusa ferrireducens sp. nov., psychrophilic, $\mathrm{Fe}$ (III)-reducing bacteria isolated from Arctic sediments, Svalbard. Int. J. Syst. Evol. Microbiol. 56, 1133-1139. doi: 10.1099/ijs.0.63639-0

Wang, Q., Garrity, G. M., Tiedje, J. M., and Cole, J. R. (2007). Assessment of the microbial ecology of ruminal methanogens in cattle with different feed efficiencies. Appl. Environ. Microbiol. 73, 5261-5267. doi: 10.1128/AEM.0 0062-07

Ward, N. J., Shepherd, T., and Wang, Z. (2014). Changes in the Surface Water Chemistry at Low Tide in Drainage Channels at East Trinity Coastal Wetland, Cairns, (August 2013). Lismore: Southern Cross University.
Warnes, G. R., Bolker, B., Bonebakker, L., Gentleman, R., Huber, W., Liaw, A., et al. (2009). gplots: various $\mathrm{R}$ programming tools for plotting data. R Package Version 2.

Wen, A., Fegan, M., Hayward, C., Chakraborty, S., and Sly, L. I. (1999). Phylogenetic relationships among members of the Comamonadaceae, and description of Delftia acidovorans (den Dooren de Jong 1926 and Tamaoka et al. 1987) gen. nov., comb. nov. Int. J. Syst. Bacteriol. 49, 567-576. doi: 10.1099/00207713-49-2-567

White, I., Melville, M., Macdonald, B., Quirk, R., Hawken, R., Tunks, M., et al. (2007). From conflicts to wise practice agreement and national strategy: cooperative learning and coastal stewardship in estuarine floodplain management, Tweed River, eastern Australia. J. Clean. Prod. 15, 1545-1558. doi: 10.1016/j.jclepro.2006.07.049

White, I., Melville, M. D., Wilson, B. P., and Sammut, J. (1997). Reducing acidic discharges from coastal wetlands in eastern Australia. Wetlands Ecol. Manag. 5, 55-72. doi: 10.1023/A:1008227421258

Willett, L. R., Crockford, R. H., and Milnes, A. R. (1992). Transformations of iron, manganese and aluminium during oxidation of a sul?dic material from an acid sulfate soil. Catena Suppl. 21, 287-302.

Wu, X., Wong, Z. L., Sten, P., Engblom, S., Osterholm, P., and Dopson, M. (2013). Microbial community potentially responsible for acid and metal release from an Ostrobothnian acid sulfate soil. FEMS Microbiol. Ecol. 84, 555-563. doi: 10.1111/1574-6941.12084

Young, B. M., and Harvey, E. L. (1996). A spatial analysis of the relationship between mangrove (Avicennia marinavar. Australasica) physiognomy and sediment accretion in the Hauraki plains, New Zealand. Estuarine Coast. Shelf Sci. 42, 231-246. doi: 10.1006/ecss.1996.0017

Yue, J. C., and Clayton, M. K. (2005). A similarity measure based on species proportions. Commun. Stat. Theory Methods 34, 2123-2131. doi: 10.1080/STA200066418

Zhou, J., Xia, B., Treves, D. S., Wu, L.-Y., Marsh, T. L., O’Neill, R. V., et al. (2002). Spatial and resource factors influencing high microbial diversity in soil. Appl. Environ. Microbiol. 68, 326-334. doi: 10.1128/AEM.68.1.326-33 4.2002

Conflict of Interest Statement: The authors declare that the research was conducted in the absence of any commercial or financial relationships that could be construed as a potential conflict of interest.

Copyright (C) 2015 Ling, Bush, Grice, Tulipani, Berwick and Moreau. This is an open-access article distributed under the terms of the Creative Commons Attribution License (CC BY). The use, distribution or reproduction in other forums is permitted, provided the original author(s) or licensor are credited and that the original publication in this journal is cited, in accordance with accepted academic practice. No use, distribution or reproduction is permitted which does not comply with these terms. 